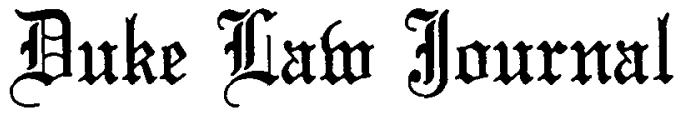

VOLUME 1979

SEPTEMBER

NUMBER 4

\section{TAXATION OF STOCK RIGHTS AND OTHER OPTIONS: ANOTHER LOOK AT THE PERSISTENCE OF PALMER $V$. COMMISSIONER}

\author{
Pamela B. GanN*
}

In 1968 an article was published entitled Taxation of "Taxable" Stock Rights: The Strange Persistence of Palmer v. Commissioner. ${ }^{1}$ Palmer had been decided by the Supreme Court in 1937,2 over thirty years prior to the writing of the article. Now, twelve years after that article, and over forty years after the Supreme Court's decision, one may continue to wonder at the "strange persistence" of Palmer. Two recent cases $^{3}$ have again raised the specter of Palmer- questioning the continuing validity of the concepts it promulgated-but each court avoided the issue by distinguishing Palmer or by finding an alternate basis for determining the tax consequences of the transactions involved. Nevertheless, the provocative questions raised by these two cases warrant another examination of Palmer and its progeny.

This Article starts at the beginning - that is, with a discussion of the transaction at issue in Palmer and with the Palmer decision itself. For all but neophytes of corporate taxation, nuch of this discussion

* Associate Professor of Law, Duke University. B.A. 1970, University of North Carolina; J.D. 1973, Duke University. The author expresses her appreciation to Professor Douglas A. Kahn for his valuable criticisms of and comments on a draft of this Article.

References to the Internal Revenue Code will be made by section number only.

1. Carlson, Taxation of "Taxable" Stock Rights: The Strange Persistence of Palmer v. Commissioner, 23 TAX L. REV. 129 (1968). Other commentators have written on the subject matter of this Article, e.g., Smith, Rights Offerings of Portfolio Securities, 26 TAx LAw. 471 (1973); Whiteside, Income Tax Consequences of Distributions of Stock Rights to Shareholders, 66 Y ALE L.J. 1016 (1957); Comment, Taxation of Stock Rights, 51 CAL. L. REv. 146 (1963); 81 HARv. L. Rev. 482 (1967).

2. 302 U.S. 63 (1937).

3. Baumer v. United States, 580 F.2d 863 (5th Cir. 1978); Redding v. Commissioner, 71 T.C. 597 (1979), appeal docketed, No. 79-1775 (7th Cir. Apr. 20, 1979). 
will be familiar. The author hopes that the experienced reader will be patient not only with this rather long history, but also with the inevitably complex factual descriptions that accoinpany almost any discussion of the taxation of corporations and shareholders.

\section{Issuance to Shareholders of Options to Purchase PROPERTY OWNED BY A CORPORATION}

A corporation may own property that it desires to sell or otherwise dispose of, and it may decide to dispose of that property by distribution to its shareholders qua shareholders. If the shareholder pays no consideration for the property, the distribution is treated as a distribution of property to which section 301 of the Internal Revenue Code (the Code) applies, and the distribution (a section 301 distribution) is taxed as a dividend to the extent of the corporation's earnings and profits. ${ }^{4}$ If the shareholder pays consideration, but the amount of consideration paid is less than the fair market value of the property distributed, the so-called "spread" between the consideration and the fair market value is treated as a section 301 distribution. ${ }^{5}$ Little dispute surrounds the tax

4. Section 301(a) provides that "a distribution of property (as defined in section 317(a)) made by a corporation to a shareholder with respect to its stock shall be treated in the manner provided in subsection (c)." In turn, subsection (c) provides that the portion of the distribution that is a dividend (as defined by section 316) shall be included in gross income. Any portion of the distribution that is not a dividend is applied against and reduces the shareholder's basis in his stock, $\S 301(c)(2)$, and any portion of the distribution that is not a dividend and that exceeds the adjusted basis in the stock is treated as a gain from the sale of property. $\$ 301(c)(3)$. The amount of the distribution subject to section 301 , if the shareholder is not a corporation, is the amount of money received plus the fair market value of the other property received. $\$ 301(\mathrm{~b})(\mathrm{I})(\mathrm{A})$. If the shareholder is a corporation, the amount of the distribution equals the amount of money received plus the lesser of the fair market value of the other property received or the adjusted basis of that property in the hands of the distributing corporation (plus any gain recognized by the corporation as a result of the distribution). $\S 301(\mathrm{~b})(\mathrm{l})(\mathrm{B})$.

Section 316 defines "dividend" as any distribution of property made by the corporation to its shareholders out of corporate earnings and profits; further, every distribution is made out of earnings and profits to the extent thereof. To complete this statutory labyrinth, section 317(a) defines "property" as used in sections 301 and 316 to inean "inoney, securities, and any other property; except that such term does not include stock in the corporation making the distribution (or rights to acquire such stock)." $\$ 317(a)$.

The effect of this scheme is that to the extent the corporation has earnings and profits, a distribution of corporate property to its shareholder in his capacity as a shareholder will be treated as a distribution of earnings and profits and, therefore, taxed as a dividend (that is, ordinary income). Corporate income is frequently said to be subject to a double tax. It is first taxed at the corporate level, and dividends paid to shareholders from corporate-source income are nondeductible by the corporation. The income is then taxed at the shareholder level as gross income of the dividend recipient.

5. Treas. Reg. $\S 1.301-1(j)$ (1979) discusses the tax consequences of a corporation's sale or exchange of property to a shareholder for an amount less than the fair market value of the property. It treats the spread between the amount paid for the property and its fair market value as a section 301 distribution. 
consequences of these two distributions.

In the alternative, a corporation may distribute to its shareholders an option to purchase the property at a designated price. The option may or may not be transferable, and it may or may not be marketable. The option price may be equal to, greater than, or less than the fair market value of the property at the date of the distribution of the option. The length of the option period may vary as well. Questions concerning the tax consequences of these options remaim unresolved, although they have been the subject of considerable litigation and commentary. ${ }^{6}$ Much of this irresolution derives from the uncertain status of the Palmer decision.

Most of the litigation concerning options distributed by corporations to their shareholders has dealt with the distribution of stock rights, which are options to purchase stock of another corporation owned by the distributing corporation. ${ }^{7}$ For example, corporation $X$ owns 10,000 shares of stock in corporation $Y$, and $X$ distributes pro rata to its shareholders the right to purchase the $Y$ shares at a designated price during a designated time period. ${ }^{8}$ Stock rights are often referred to as either "taxable" or "non-taxable" rights. The term "taxable rights" usually refers to rights that, either when issued or exercised, are taxed under section 301 and thereby yield mcome tax consequences to the shareholders. The term "nontaxable rights" usually refers to a situation in which the issuance of the rights is protected by a nonrecognition provision of Subchapter C of the Code.?

Options may, of course, be issued by a corporation to its sharelolders for the purchase of other types of corporate property-for example, a tract of land owned by the corporation. Although options for the purchase of other property have not often been the subject of litigation, they raise issues similar to those associated with the distribution of options designated as stock rights. This Article addresses the tax consequences associated with the distribution by a corporation of either stock riglits or other types of options to shareholders. ${ }^{10}$ Part II dis-

6. See note 1 supra.

7. These shares frequently are called "portfolio shares."

8. Stock rights are frequently traded on the stock market when issued. The issuance of such rights usually serves two corporate purposes: (1) benefitting the corporation's shareholders by disposing of the stock to them, often at a bargain price, and (2) raising additional capital by having the corporation's sliareholders pay for the distributed stock.

9. See text accompanying notes 135-64 infra for a discussion of the issuance of stock rights in connection with a corporate division under section 355 .

10. The options discussed in this Article should be distinguished from two other types of options. First, this Article is not about employee stock options, which are taxed to the employee as compensation income, or about options given to persons other than shareholders. Employee stock options are discussed later in this Article, lowever, to the extent their taxation suggests analogies 
cusses the distribution of taxable options, and Part III discusses the use of stock rights in connection with corporate divisions that are nonrecognition transactions nnder section 355 of the Code.

Part II begins with Palmer, which involved the issuance of taxable stock rights, and continues with a detailed discussion of subsequent cases that developed the principles derived from Palmer. Part II then discusses the soundness of the interpretations of the Code in these decisions, the economic reality of the tax consequences, and the ease of administration of the tax consequences. A secondary purpose of the discussion in Part II is to illustrate for courts and tax practitioners the manner in which the principles developed in Palmer and subsequent cases actually operate under varying factual situations.

\section{Issuance to Shareholders of TAXable Stock Rights AND Other TAXABle Options}

\section{A. Palmer v. Commissioner. ${ }^{11}$}

Mr. Palmer, a shareholder of the American Superpower Company (Superpower), received from Superpower rights to purchase common stock of the United Corporation (Uinted) held by Superpower, The Board of Directors of Superpower authorized the rights offering on January 23, 1929. Each shareholder was granted the transferable right to purchase, at twenty-five dollars per share, one-half share of United stock for each Superpower share. The rights were distributed on January 31 and expired on February 15. Mr. Palmer exercised his rights on February 15. He did not report the receipt of income on either the issuance or the exercise of the rights. The Government argued that the issuance of the rights was a dividend equal to the fair inarket value of the rights on the date the shareholder was first entitled to exercise them. ${ }^{12}$

to the taxation of options issued to shareholders. See text accompanying notes 70-89 infra. Second, this Article is not about the taxation of stock rights to purchase the issuing corporation's own stock; these rights are taxed under section $\mathbf{3 0 5}$ as stock dividends. Before the enactment of the 1954 Code, however, many of these rights were taxed similarly to rights to purchase other property owned by the distributing corporation. Consequently, some of the cases discussed in this Article concern rights to purchase stock of the distributing corporation. They are relevant to the judicial development of the Palmer principles prior to the 1954 Code.

11. 32 B.T.A. 550 (1935), rev'd, 88 F.2d 559 (1st Cir.), rev'd, 302 U.S. 63 (1937).

12. Even before the Palmer decision, the lower courts had been wrestling with the same issues-whether the issuance of a stock right was a distribution, and if so, whether the distribution for tax purposes occurred at the time the right was received or at the time the right was exercised. See, e.g., Commissioner v. Palmer, 88 F.2d 559 (Ist Cir.) (distribution occurs when stock right is exercised), rev'd, 302 U.S. 63 (1937); Commissioner v. Mayer, 86 F.2d 593 (7th Cir. 1936) (fair market value of stock was apparently greater than option price on date of issuance; nevertheless, court determined it did not have to decide whether to use date of issuance or date of exercise as 
The Supreme Court concluded that at the time the rights offering was adopted (January 23), the Board of Directors of Superpower did not intend to distribute a dividend because the twenty-five dollar offering price, in conjunction with the Board of Tax Appeals' finding that the fair market value of the stock was also twenty-five dollars on that date, ${ }^{13}$ indicated that the Directors intended only a sale of the United stock. ${ }^{14}$ The Court, however, still had to determine whether the ensuing distribution of the United stock should be characterized as a dividend, either because rights to subscribe were selling on the stock exchange at substantial prices, or because the stock itself was selling at prices substantially above the stipulated purchase price.

In answering this question, the Court first stated that a sale of property for less than its fair market value would be a distribution of profits, as would a fornal declaration of a dividend. ${ }^{15}$ But the distribution of a right to purchase property, as opposed to a distribution of the

time of distribution, because fair market value of stock subject to option did not fluctuate between the two dates, so that the spread was identical on dates of issuance and exercise), rev'd per curiam, 302 U.S. 647 (1937); Ramapo, Inc. v. Commissioner, 84 F.2d 986 (2d Cir. 1936) (distribution occurs when stock right is received); Helvering v. Bartlett, 71 F.2d 598 (4th Cir. 1934) (issuance of stock right was not a distribution; moreover, no distribution occurred when right was exercised, evidently because court did not find option price to be less than fair market value of propcrty subject to option).

13. The United stock sold for $\$ 22.50$ on January 9, but on January 29,30 , and 31 , it sold for $\$ 50$ to $\$ 63$ per share. Shortly after the adoption of the rights offering on January 23 , an active market for the rights developed. On January 25 (six days before the rights were actually issued), the rights were trading at $11 \mathrm{~s} / 8$ to $12 \%$, making the cost of the Umited stock to purchasers of the rights about $\$ 50$ per share (since the exercise of two rights plus payment of $\$ 25$ was necessary for the distribution of a share of $Y$ stock). On January 28, three days prior to the issuance of the rights, the rights were trading at $12 \%$ to $17 / 2$, making the cost to the purchasers of the rights $\$ 50$ to $\$ 60$ per share.

Notwithstanding all of the contrary evidence of the value of the United stock and of the rights resulting from the trading of the stock and the rights, the Board of Tax Appeals found that the fair market value of the United stock during January was $\$ 25$ per share. 32 B.T.A. at 554, 557. The stock might have been valued at $\$ 25$ per share at about the time of the Board's action on January 23 , but clearly by the time the rights were issued (January 31 ), the Unitcd stock had a value substantially in excess of $\$ 25$ per share and the rights themselves were trading at prices above $\$ 10$.

14. The facts stipulated and the finding of the fair market value of the United stock at the time of the adoption of the first plan for its distribution abundantly sustain the board's conclusion that the transaction-in forn a sale-was not intended to be the means of a distribution of earnings to stockholders.

302 U.S. at 70. The Board of Tax Appeals had also concluded that the distribution of the United stock was a sales transaction since, under the facts, the Board of Directors could not have intended a dividend distribution. 32 B.T.A. at 560-61. The First Circuit, on appeal, thought the Board of Tax Appeals had disregarded all of the contrary evidence of value because it had assumed Superpower never intended to distribute corporate earnings. The appellate court rejected this intent test and held that the difference between the fair inarket value of the United stock and the option price of $\$ 25$ on the date the right was exercised was a dividend distribution. 88 F.2d at 562 .

15. Treas. Reg. $\$ 1.301-1(j)(1979)$ is consistent with this statement in Palmer since it treats the spread between the fair market value and the sales price as a section 301 distribution. 
property itself in kind, was not a dividend because there was no distribution of corporate assets, even though the rights theinselves may have had a market or exchange value. A right to purchase property was characterized as a continuing offer to sell and a potential source of income to be realized through its sale or exercise. ${ }^{16}$

After the Court had concluded that the grant of the option was not a dividend, it turned to the question of whether there could nevertheless be a dividend upon the exercise of the option if the value of the property at that time was more than the purchase price. The Court refused to find that a sales transaction was converted into a dividend by subsequent changes in the market price. Because the option period was

16. The Court cited two other Supreme Court cases in support of its characterization of a right as not a distribution of corporate assets. In Miles v. Safe Deposit \& Trust Co., 259 U.S. 247 (1922), the Court considered whether a shareholder of Corporation $X$ recognized a gain on the sale of rights, distributed pro rata to the common shareholders of $X$, for subscription at a certain price to additional $X$ common stock. To answer that question the Court had to determine the shareholder's basis in the rights. (At this time, rights to purchase the stock of the distributing corporation and to purchase other property of the corporation were taxed under similar principles. See note 10 supra). The Court in Miles stated that the distribution of the right itself did not constitute a division of any part of the corporation's capital or earnings and therefore was not a taxable event. By analogy to Eisner v. Macoinber, 252 U.S. 189 (1920), if the issuance of a coinmon stock dividend itself would not be taxable because there was no distribution or severance of corporate property, then the issuance of a right to receive additional common stock should also not be treated as a severance of corporate property. Miles may be distinguished from Palmer because Miles concerned a right to purchase additional stock of the distributing corporation. As discussed later in this Article, see text accompanying notes 114-25 infra, the distribution of an option or right to purchase other property owned by the corporation-unlike the issuance of a stock dividend or a stock right to purchase the issuing corporation's own stock-is arguably a distribution of property of the distributing corporation on the date of issuance of the option or right.

The Court in Palmer also cited Helvering v. San Joaquin Frnit \& Inv. Co., 297 U.S. 496 (1936). In that case, a lessor gave a lessee an option in 1906 to purchase the property subject to the lease. The option was exercised on November 30, 1916. The issue was whether the lessee's acquisition of a right to purchase the leased property constituted the acquisition of the land itself, or whether the land was deemed to have been acquired on the date the option was exercised. The date of acquisition was inportant because the taxpayer's basis in the land would be greater if the taxpayer were deemed to have owned the land on March 1, 1913 (so that the taxpayer's basis would be determined by reference to the fair market value of the property on that date), rather than to have acquired the land in 1916 when the option was exercised (so that the taxpayer's basis would be equal to the sum of the option price plus the value of the capital improvements made by the lessee on the land during the tern of the lease). The Court held that, even though the option itself was clearly valuable, it did not transfer ownership of the underlying property itself; rather, the property was acquired when the option was exercised. This case did not concern the distribution of an option by a corporation to its shareholder, but an option issued in a commercial transaction in which the parties were dealing at arm's length. Therefore, the facts in San Joaquin are inapposite. Nevertheless, the case might have been cited for the proposition that the receipt of an option cannot itself be the receipt of something of value that may immediately be subject to tax. The Court in San Joaquin indicated that a taxable gain would not occur until the lessee sold the option at a profit, $i d$. at 498 , or if the option were exercised, until the underlying property was sold. See id. at 500 . 
short (fifteen days), the Court viewed the rights offering as merely the mechanical process pursuant to which the sale to the shareholders could be completed. Superpower could not expect to execute every sale on January 23; therefore, Superpower might have expected the subsequent market prices of the United stock to shift. The Court noted that subsequent fluctuation in market price is a problem associated with all ordinary commercial transactions in which an offer is kept open for acceptance during a brief period, or in which performance is delayed beyond the execution date of the contract. In commercial transactions, the buyer does not incur a tax on the change in value of the property between the dates of offer and acceptance. The Court felt that the sale of United stock by Superpower to its shareholders through the mechanisin of a rights offering was in fact identical to a commercial transaction and should be so treated for tax purposes.

Aside from the questionable finding that twenty-five dollars was the fair market value of the $Y$ stock on January $23,{ }^{17}$ the Palmer opinion raises several substantive issues. Is the determination of whether a dividend occurred dependent upon a subjective "intent" test? May one limit the application of Palmer to situations in which the court concludes that the option price equals the fair market value of the property on the date of authorization by the Board, or perhaps even on the date of issuance? Or may one limit the apphication of Palmer to situations in which the option price equals the fair market value of the property on the date that the price is selected and the option period is ouly a few days? Or does Palmer extend further to mean that no issuance of an option-even when the option price is less than the fair market value of the property on the date of the Board's action or on the date that the option is issued-is itself ever a taxable distribution to shareholders? Subsequent cases have addressed these and related questions. The judicial developnent of the Palmer principles ${ }^{18}$ by the lower courts will

17. See note 13 supra.

18. The collective judicial interpretations of the Palmer case are sometimes referred to as the "Palmer principles" or the "Palmer doctrine." These principles are technically derived from dicta in the Palmer opinion. The Court's holding in Palmer may be summarized as follows: when a corporation effectuates a sale of property to its shareholders through a rights offering, and the option price fixed by the Board of Directors equals the fair market value of the property (thereby indicating the Board's intent to make a sale), a distribution of the property to shareholders pursuant to the exercise of the rights is not taken out of the sales category and placed in the dividend category even though before exercise the rights themselves are sold at substantial prices or the property itself is sold at prices above the option price. It was not necessary in reaching this holding for the Court also to make more general statements about the tax consequences of the issuance and exercise of options. Nevertheless, the Court's opinion is like an advisory opinion on this subject. For example, the opinion states that "[t]he mere issue of rights to subscribe and their receipt by stockholders, is not a dividend . . . Taxable income inight result from their sale, but distribution of the corporate property could take place only on their exercise." 302 U.S. at 71 . 
be first described and then evaluated.

\section{B. Judicial Development of the Palmer Principles.}

1. Exercise of Stock Rights. The first important opportunity to analyze the Palmer decision came five years later in Choate v. Commissioner. ${ }^{19}$ In that case, the common shareholders of the Crane Company (Crane) were given the right to purchase, for $\$ 100$, one share of Crane preferred stock for every twelve shares of Crane common stock. ${ }^{20}$ The rights were received on May 28, 1937, and the fair market value of the rights on that date was forty-four cents. The rights expired on June 17, and they traded on June 15-16 at two cents. The preferred stock traded during this period (on a when-issued basis) at $\$ 104$ on June 1 and at $\$ 100-3 / 16$ on June 17. Thus, a spread existed between the option price and the fair inarket value of the stock on the date the rights were received, and that spread was greater when the rights were first received than on the expiration date. Mr. Choate received his rights on May 28; on June 15, he gave them to family members; and the donees exercised the rights on June 17.

The Second Circuit's opinion, written by Judge Frank, summa-

Technically, this statement is a dictum; but because of the straightforward, unqualified nature of the statement, a federal judge in a lower court would normally believe himself compelled to follow this dictum and treat it as a holding, unless he formulated convincing reasons for rejecting it. See, for example, the discussion at text accompanying notes 19-33 infra (Judge Frank's derivation of the "Palmer principles" from this and other dicta in the Palmer opinion). Although these dicta were converted into holdings by lower court decisions after Palmer, the author uses the words "dictum" and "dicta" when referring to the statements in Palmer because this categorization of the statements in the context of Palmer itself is correct. The distinction between the actual holding of Palmer and the Palmer dicta that subsequent cases have accorded the weight of holdings is important in avoiding the perception of incongruity in questious posed by this Article: for example, what is the continuing validity of the dicta in the Palmer case after the enactment of the 1954 Code? A more correct formulation of the question may be whether a court should feel compelled to follow the advisory opinion of the Court in Palmer after the enactment of the 1954 Code.

19. 129 F.2d 684 (2d Cir. 1942).

20. It should be noted that, unlike Palmer, which concerned rights to purchase shares of another corporation owned by the distributing corporation, Choate involved rights to purchase shares of the distributing corporation. The Second Circuit nevertheless concluded that Palmer applied. It reasoncd that since the direct issuance of a preferred stock dividend would have been taxable as a dividend, the issuance of a right to purchase the preferred stock should also yield a taxable dividend when exercised. 129 F.2d at 688. In Choate, rights to subscribe to preferred stock wcre issued to common shareholders when the corporation had other preferred stock outstandimg. The court thought these rights were taxable even though the preferred stock was convertible into common. Id. at 688 n.12. See also Strassburger v. Commissioner, 124 F.2d 315 (2d Cir. 1941), rev'd, 318 U.S. 604 (1943). The court in Choate distinguished Miles, see note 16 supra, because Miles concerned the issuance to common slareholders of a right to purchase common stock. Since the direct issuance of a common stock dividend would not have been taxable under Eisner v. Macomber, 252 U.S. 189 (1920), the issuance of a right to purchase such stock was not taxable as a dividend. Presently, under section 305, a preferred stock dividend issued to common shareholders in a Choate situation may not be a taxable distribution. 
rizes the tax consequences of the issuance of stock rights. This summary, based upon the court's interpretation of Palmer, ${ }^{21}$ is important because it has been followed with relative consistency since the Choate opinion. First, the Second Circuit stated that if the corporation issues an option to its shareholders, and if on the date of issuance no spread exists between the option price and the fair market value of the property, there is no corporate intent to distribute profits and thus no dividend. ${ }^{22}$ Second, if a spread exists at the time of issuance, the court will find that the corporation intended to distribute a dividend equal to the spread. ${ }^{23}$ Third, even if a spread exists and the imtent to distribute a dividend is evident, the issuance of the option is merely an offer to make the distribution. ${ }^{24}$ There is no dividend distribution unless and until the option is exercised. Fourth, the amount of the dividend upon the exercise of the option is the lesser of the spread on the date the option is granted or the spread on the date the option is exercised. ${ }^{25}$ Applying this summary to the facts in Choate, the court noted that on the date of issuance a spread existed between the option price and the fair market value of the stock, so that a dividend was intended. A smaller spread also existed on the date of exercise; therefore, applymg the "lesser of" rule, the amount of the dividend was equal to the spread on the date of exercise.

Portions of the court's summary of the Palmer decision are sound. In connection with the first two parts of the summary, Judge Frank established that corporate intent is determined primarily by an objective test: the intent to make a distribution hinges on the existence of a spread on the date of issuance. ${ }^{26}$ This method of determining corporate intent is clearly correct. It relies upon objective evidence of the econonnic effect of a transfer of property to a shareholder, and it avoids the obvious administrative difficulties associated with a more subjective intent test. If this objective test is rigidly applied, however, it can lead

21. In Choate, the court rejected the argumeut that the issuance of the stock right could be taxed uuder section 22(a) of the 1939 Code (the predecessor to section 61 of the 1954 Code) which set forth the broad definition of gross income. 129 F.2d at 689. The court's statement that the tax analysis of the distribution depended upon the statutory definition and treatment of dividends suggests that the broad definition of gross incone used by the Supreme Court in interpreting section 22(a) and section 61(a) in subsequent opinions, see, e.g., Commissioner v. Glenshaw Glass Co., 348 U.S. 426 (1955), has no application to the problem of the taxation of options distributed to shareholders. Coinpare the tax treatment of employee stock options discussed at text accoinpanying notes $70-89$ infra.

22. 129 F.2d at 686 .

23. Id. at 687.

24. Id.

25. Id.

26. Id. at 686 n.4. 
to incorrect results. For example, Judge Frank's first conclusion-if no spread exists at issuance, there is no corporate intent to distribute a dividend-is probably valid when the option period is very short, as in Palmer and Choate. When the option period is inuch longer, however, this conclusion is not necessarily true. In such cases, the corporation maý anticipate that a spread will develop and intend to benefit its shareholders by distributing that spread to them through the issuance of an option. ${ }^{27}$ Thus, Judge Frank's first point should be limited to issuances with a short option period. Further, Judge Frank himself recognized that his second conclusion should also be carefully limited. He correctly indicated that even if a substantial spread does exist at the time of issuance, such a spread is neither necessary nor sufficient to deinonstrate the intention to inake a distribution, but is merely good evidence of that intention. Indeed, Judge Frank specifically stated: "It is conceivable that there might be a case in which it could be shown that, despite such a spread, no distribution of corporate earnings was intended. But there would be a lieavy burden on the taxpayer seeking so to show."28 This treatinent of the objective evidence of a spread is clearly correct. By refusing to hold that the existence of a spread is conclusive evidence of a dividend, the court still allowed the taxpayer to prove that the corporation did not intend to distribute earnings and profits, and thereby avoided the danger of characterizing legitimate commercial sales transactions between corporations and shareholders as dividends. ${ }^{29}$

27. See Commissioner v. Smith, 324 U.S. 177 (1945), discussed at text accompanymg notes 71-75 infra (Supreme Court concluded that a corporation intended to compensate an employee by issuing to him an option under which a spread between the fair market value and option price was expected to develop during the option period). Also see Baumer v. Umited States, 580 F.2d 863 (5th Cir. 1978), discussed at text accompanying notes 117-25 infra (Fifth Circuit concluded that a corporation issumg an option to a shareholder intended a distribution pursuant to the developInent of a spread between the fair market value and option price during the option period).

28. 129 F. $2 d$ at 687 n.5.

29. Some courts, however, have treated any bargain element in a sale by a corporation to its shareholder as a distribution of corporate earnings and profits. See, e.g., Honigman v. Commissioner, 466 F.2d 69 (6th Cir. 1972), and cases cited therein. In Honigman, a corporation was about to adopt a plan of liquidation under section 337 and wanted to sell certain property prior to the adoption of the plan, since the property's fair market value was less than the corporation's adjusted basis in the property and the property would thus be sold at a loss. A shareholder offered the best price the corporation received. The court accepted proof by the Internal Revenue Service that the actual fair market value of the property at the time of its sale to the shareholder was greater than the price paid by the shareholder. The court held that this bargain element was a distribution of corporate eamings and profits, which had to be taxed as a dividend. The facts of the case arguably suggest, however, that no corporate intent to make a distribution existed. At the time the corporation wanted to sell the property, it solicited purchasers at large and did not find any purchaser willing to pay the fair narket value of the property as deternined by the court. This factor suggests the transaction appropriately should have been treated as a commercial trans- 
Further analysis of the Choate opinion, however, discloses several serious flaws in Judge Frank's summary. In deriving the rules from the Palmer case, he used the date of issuance to determine whether a substantial spread existed and, in turn, whether the corporation intended a distribution of earnings and profits. The Court in Palmer, on the other hand, had determined corporate intent by reference to the earlier date on which the corporation committed itself to issue the option at a certain price..$^{30}$ In fact, there clearly was a spread on the date of issuance in Palmer, but the Court in Palmer found no spread on the earher date and therefore no intent to make a distribution. In order to state a rule that covered every situation and correctly interpreted Palmer, the court in Choate should have looked to the date on which the corporation selected the option price. ${ }^{31}$

A more serious flaw in the Choate opinion is the fourth point in Judge Frank's summary of Palmer - the "lesser of" rule. This rule assumes that the corporation would never intend to declare a dividend greater than the spread on the date of issuance and that the annount of the actual distribution would never be greater than the anount "distributed" (that is, the spread) on the date of exercise. Unless the option period is very short, however, the first assumption underlying the rule ignores the possibility that a Board of Directors inight create a spread on the date of issuance and sinultaneously anticipate that the spread would increase before the option period expired. Their intent could therefore be inore flexible than the intent ascribed to the directors in Choate. The second assuinption, that actual distribution is never greater than the spread at exercise, is based upon dicta in the Palmer opinion setting the tune of the distribution at the tinie of exercise and intplying that the dividend amount is also measured on the date of exercise. ${ }^{32}$ But other dicta in Palmer suggest that the ainount of the dividend is the annount intended by the Board of Directors, which is best determined at the tinie they decide to issue rights. ${ }^{33}$ Despite the apparent conflict, the "lesser of" rule incorporates both portions of the Palmer decision, and so may yield the anonalous result that the time

action in which the buyer was able to extract a bargain element because the seller wanted to dispose of the property quickly.

30. The Court stated in Palmer. "Price, which in the present case is decisive of the issue, must be determined in the light of the situation existing when price is fixed. If the option price is fair when fixed the transactiou is a tender for a sale and not for a distribution of profits . . .." 302 U.S. at 72.

31. Of course, it is possible that the option price would in fact be set by the directors on the date of issuance. In that case, the Second Circuit would certainly be correct in determining the existence of a spread on the date of issuance.

32. 302 U.S. at 69.

33. Id. 
of the distribution is the date of exercise, but the amount distributed on that date is determined by reference to the date the Board sets the price.

This result is unsound. Palmer requires a finding of corporate intent to distribute its profits, but it does not follow from this requirement that the amount of a dividend actually distributed is the same as the amount of profit the corporation imtended to distribute. The threshold finding of intent to distribute profits is necessary in order to distmguish a commercial sale, im which the purchaser obtains a bargain, from a deliberate distribution of a bargam element to a shareholder-purchaser pursuant to a part-sale, part-dividend transaction. Once the transaction is classified as a dividend by looking at corporate intent, however, the amount of that dividend should be determined by the actual economic effect of the transaction rather than by the amount of distribution intended by the corporation. For example, corporation $X$ (having anple earnings and profits) declared a dividend of Blackacre on January 1 , to be distributed to its sole shareholder on March 1. The fair inarket value of Blackacre was $\$ 10,000$ on January 1 and rose to $\$ 11,000$ on March 1. The corporation may have intended a dividend of $\$ 10,000$ when the dividend was declared, but the actual anount of the dividend was $\$ 11,000$, the value on the date of distribution. Similarly, if under Palmer the date of the dividend distribution is the date of exercise, the alnount of the distribution should be determined by the spread on the date of exercise in order to reflect the economic realities of a distribution. Because the adoption of the "lesser of"rule in Choate was not mandated by the Palmer decision, and because it may incorrectly determine the amount of a distribution to a shareholder by reference to the date that the corporation issues the option, it should not be followed in the future.

2. Sale of Stock Rights. Although the tax consequences of the sale of a right prior to expiration were not an issue in Choate, the court noted in dictum that it would have trouble concluding that the income froin the sale of a right should be treated as a dividend, because under the Palmer analysis no dividend can occur except upon the exercise of the right. ${ }^{34}$ Only one year later, the Second Circuit had the opportunity to address this issue directly in Gibson $v$. Commissioner, ${ }^{35}$ a case involving the issuance of rights to purchase portfolio shares. A spread existed between the option price and the fair market value of the stock on the date of issuance; consequently, under the Choate analysis, the corporation intended to distribute a dividend. The distribution did not occur,

34. See note 16 supra and accompanying text.

35. 133 F.2d 308 (2d Cir.), appeal dismissed, 320 U.S. 805 (1943). 
however, until the option was exercised. Before the expiration of the option period, the taxpayer sold her rights at a gain.

The Commissioner had treated the receipt of the rights as a dividend equal to their fair market value $(\$ 12,225)$ on the date of issuance. Later, when the rights were sold for $\$ 13,728$, the Commissioner treated the excess of that anount over the basis as a capital gain. But the Second Circuit, applymg the third part of the Choate analysis, held that issuance alone was not a dividend distribution. Nevertheless, the issuance gave the taxpayer an opportunity to receive ordinary (dividend) incoine to the extent of the spread between the option price and the stock's fair market value at the time of issuance. The proceeds of the sale of the rights, therefore, at least to the extent of the spread, were also treated as ordinary imcome. Any amount received in excess of the spread was not intended to be a dividend distribution and therefore was taxed as a capital gain.

In concludimg that the sale of the right yielded ordinary income, the court in Gibson applied the anticipation of income doctrine. ${ }^{36} \mathrm{Or}$ dinarily, a stock right would be an itein of property treated as a capital asset and would yield capital gain or loss upon its sale. In this instance, however, the gain on the sale of the right represented the spread that would have been taxed as ordinary income if the right had been exercised rather than sold. Therefore, under the anticipation of incoine doctrine, the spread inust be taxed as ordimary income to the extent that the seller's exercise of the right would have yielded a dividend.

Although the seller of the right clearly realizes ordimary income, it is difficult to see how that income can be treated as a dividend distribution. Under Palmer, as interpreted by Choate, no dividend distribution occurs until the option is exercised. If an option is merely sold to a third party, the property underlying the option has still not been dis-

36. The Code distinguishes between gain that is realized through the sale of property and income that is received periodically. Sale gains frequently are treated as capital gains, while periodic receipts are treated as ordinary income. For example, if a taxpayer sells a share of stock at a gain, it is a capital gain for tax purposes. If, however, the taxpayer retains the share of stock and receives dividends each year, the dividends are taxed as ordinary imcome. Taxpayers have attempted to realize capital gains by selling a portion of the periodic income streain. For example, an owner of a share of stock may sell the right to receive dividends paid on that stock for the next ten years. Should the incoine received froin the sale of the right to receive dividends be treated as capital gain or ordinary income? In answer to that questiou, the courts have developed the "anticipation of income" doctrine: if the actual receipt of incoine would have yielded ordinary income, then the anticipation of that income through a sale of the right to the income also yields ordinary incoine. See, e.g., Commissioner v. P.G. Lake, Inc., 356 U.S. 260 (1958); Hort v. Commissioner, 313 U.S. 28 (1941). In the example above, the price paid for the right to receive future dividends is taxed as ordinary income. This doctrine prevents the avoidance of ordinary income that would oceur if the "anticipation of inconne" were allowed to be treated as a capital gains transaction. 
tributed by the corporation, and therefore, no dividend distribution has yet occurred. This conclusion is important because the classification of the income as a dividend may determine the seller's right to offset the ordinary income realized from the sale by the exclusions provided in section 116 or section $243 .^{37}$

Another difficult question arises when a right is sold: How much of the proceeds from the sale should be taxed as ordinary mcome? The Second Circuit in Gibson stated that the proceeds from the sale of the rights must be treated as ordinary income at least to the extent of the spread on the date of the issuance of the right. ${ }^{38}$ This statement is imprecise and unaccompanied by any analysis in this opimion, so the question must be discussed without assistance from the Gibson opinion itself.

The amount of ordimary mcome under the anticipation of income doctrine depends upon the amount of ordimary income that the shareholder would have realized had the right been exercised rather than sold. That amount normally cannot be determined because it depends upon the amount of the spread on the date of a hypothetical exercise, which could occur on any date during the option period. If one were to apply the Choate rule that the aniount of the distribution is equal to the lesser of the spread on the date of issuance or on the date of exercise, again the spread on a hypothetical date of exercise could not be determined and one necessary part of that rule could not be supplied.

Since the correct measure of anticipated imcome is the spread on some lypothetical exercise date, and smce that date cannot be known, soine otlier date must be chosen - either the date of issuance or the date on which the right is sold. The date of issuance provides a uniform rule for all shareholders who sell their rights; and when rights are issued to a substantial number of shareholders and a market for the rights develops, the uniformity of the rule is administratively attractive. ${ }^{39}$ The use

37. See text accompanying note 44 infra.

38. 133 F.2d at 309.

39. Moreover, support for this date can be dervied by analogy to sections 305 and 306 . Under section 305 , if preferred stock is issued as a stock dividend with respect to common stock, the receipt of the preferred stock normally is not taxed as a dividend because the interests of the shareholders in the distributing corporation are not changed as a result of the distribution. A subsequent sale of the preferred stock, however, will frequently yield ordinary income under section 306 . Because preferred stock can be distributed pro rata to common shareholders without tax consequences under section 305(a), Congress was concerned that preferred stock dividends would be used as a mechanism to avoid dividends taxed as ordinary imcome. For example, the sole shareholder, $A$, of Corporation $X$, which has aceumulated earnings and profits of over $\$ 150,000$, could cause $X$ to distribute a dividend on his common stock of preferred nonvoting stock having a fair market value of $\$ 100,000$, and $A$ could then sell the preferred stock to $B$, an unrelated party, for $\$ 99,000$. $X$ could then redecm the preferred stock seriatim over a five-year period. In effect, $A$ 
of the issuance date presents one problem, however, that could be avoided if the sale date were used to determine the amount of anticipated incoine. A shareholder receiving the right under a date of issuance rule could, during the option period, have the choice of selling the right (with ordinary incoine equal to the spread on the date of issuance) or of exercising the right (with ordinary income equal to the spread on the date of exercise). If the spread were less on the date of issuance than on the date of exercise, the shareholder would receive sale proceeds representing the higher spread on the date of sale. Not all the proceeds would be ordinary imcome, however, because ordinary incoine from the sale would be ineasured by reference to the date of issuance. This potential for tax reduction could be avoided by a rule that the spread on the date of sale be used to measure ordmary mcome from the sale of a right. Under this rule, the proceeds from the sale should approximate the spread on the date of sale, and the shareholder should realize approximately the same amount of ordinary income whether the right is sold or exercised. Consequently, the imvestment choice is tax-neutral. The factor of neutrality suggests that using the spread on the date of sale to measure the amount of ordinary income realized on that sale is preferable. This choice yields a more cumbersome administrative result in the case of rights issued by a corporation with many sliareholders, since those shareholders will sell the rights on varying dates, and spreads will vary with the dates. This factor should not be given significant consideration, however, because under the Palmer doctrine it appears identically in the determination of the amount of ordinary income realized upon the exercise of any right.

The discussion concerning the tax consequences of the sale of rights lias assumed that the distributimg corporation has earnings and profits that exceed all the distributions-those upon exercise and those

would have withdrawn $\$ 99,000$ from the corporation, and the excess of that amount over his basis would be taxed to him at long-term capital gains rates. The cost to $A$ of transmuting the withdrawal from a dividend, taxed at ordimary imcome rates, to a capital gain, is the extra $\$ 1,000$ paid to $B$ by the corporation when the preferred stock is redeemed, plus the dividends paid to $B$ on the preferred stock during the five-year period prior to final redemption. This latter dividend cost is borne by the corporation without tax consequences to $A$. In 1954 Congress sought to foreclose this possibitity by providing in section 306 that the disposition of such preferred stock would cause the recognition of ordinary income. Subsection (a) of that section provides that if the preferred stock is sold, the amount realized is treated as ordimary mcome to the extent the shareholder would have received a dividend if $m$ heu of the preferred stock the corporation had distributed money equal to the fair market value of the preferred stock at the time of its distribution. Thus, under section 306 , the amount of ordmary income when the preferred stock is sold is determined by reference to the date the stock is issued. This suggests by analogy that the annount of ordinary income realized when a right is sold could be determined by reference to the anount of ordinary imcome that would have been received on the date the right was issued, if the right had been exercised on that date or if money equal to the spread on that date had been distributed in heu of the right. 
anticipated through sales. Under this assumption, the determination of the tax consequences to the shareholder who sells a right is straightforward: the proceeds from the sale are taxed as ordinary imcome (simce there are ample earnings and profits) to the extent of the spread on the date of sale (or, alternatively, as discussed above, on the date of issuance), and any proceeds im excess of that spread are taxed as a capital gain. ${ }^{40}$ For example, a corporation that has ample earnings and profits distributes to its shareholder, Corporation $S$, the right to purchase one share of $X$ stock for $\$ 5$. The distributing corporation has a basis of $\$ 10$ in the $X$ share, and the fair inarket value of the $X$ share is $\$ 18$. On the date the right is issued, $S$ sells the right to $A$, for which $A$ pays $\$ 13$. How is the $\$ 13$ received by $S$ characterized? If $S$ had exercised the right, $S$ would have received ordinary imcoine of only $\$ 5$, since the $\$ 8$ excess of the value of the $X$ share over the distributing corporation's basis therein would not constitute an anount distributed to $S^{41}$ Therefore, only $\$ 5$ of the sale price is ordinary incoine to $S$, and the reinaining $\$ 8$ is a short-tern capital gain. ${ }^{42}$ When $A$ exercises the right, the distribution of the $X$ stock is not a dividend distribution to $A$ because $A$ receives the distribution as a purchaser, not as a shareholder of the distributing corporation. $A$ 's basis in the $X$ share is $\$ 18$, the sum of the $\$ 5$ option price paid to the distributing corporation plus the $\$ 13$ purchase price for the right paid to $S$.

3. Lapse of Stock Rights. If a spread exists on the date of the issuance of a stock right so that it can be inferred that the corporation mtended to distribute a dividend upon exercise, the shareholder will nevertheless recognize no income or loss when the option period lapses if the shareholder neither sells nor exercises the right during the period. ${ }^{43}$

4. Application of Section 116 and Section 243. Since a corporation unay not deduct the payment of dividends, its incoine nornally is taxed twice--once to the corporation and again when it is distributed as a dividend to the shareholder. In the case of an individual shareholder, section 116 alleviates this double taxation by excluding from an indi-

40. If the distributing corporation's earnings and profits are less than the suin of the distributions inade by the corporation upon the exercise of the rights and the distributions that are anticipated through the sale of the rights, the determination of the tax consequences to shareholders who either exercise or sell the rights is inore complicated. See text accompanying notes 53-58 infra.

41. See example 2 in note 52 infra.

42. The application of section 243 to the sale of a right is discussed at text accompanying note 44 infra.

43. Eastern Shares Corp., 32 B.T.A. 608 (1935). 
vidual's gross income the first $\$ 100$ of dividends received from domestic corporations. In the case of corporate shareholders, Congress was concerned that corporate income not be subject to more than double taxation. For example, assume that corporation $X$ is a shareholder of corporation $Y$, and that $X$ is wholly owned by individual $A$. If corporation $Y$ pays a dividend to corporation $X$, that dividend is reported as income by $X$, and then if it is distributed by $X$ to $A$ it is taxed again to $A$. Thus, the income earned by $Y$ is taxed at three levels. To lessen this problein of multiple taxation, section 243 allows a corporate shareholder a deduction equal to eighty-five percent of the dividends received froin domestic corporations, thereby taxing, im effect, only fifteen percent of total dividends received. In the preceding example, because of the section 243 deduction taken by $X$, the mcome earned by $Y$ will be subjected essentially to two taxes-once to $Y$ and then again to $A$.

If the exercise of a right by an individual or corporate shareholder results in a dividend distribution, section 116 and section 243 can be applied by the individual and corporate shareholder, respectively. If, however, the rights are sold rather than exercised, do section 116 and section 243 apply? Again, the same difficulty exists that was noted by the court in Choate - how can such a sale yield a dividend when Palmer states that no assets or earnings of the corporation are distributed until the rights are exercised? The single case that has addressed this specific issue, Tobacco Products Exports Corp. ${ }^{44}$ held that a corporation was entitled to the dividends-received credit on the proceeds from the sale of stock subscription rights, but the court reached that result with little discussion of its analytical foundation. If the Tobacco Products court had ventured into a more thorough analysis, it might have reached the opposite result. That is, even though the Gibson court applied the anticipation of income doctrine $e^{45}$ to hold that the gain received on the sale of a right should be treated as ordinary income to the extent that the exercise of the right would have yielded ordinary income, it does not follow that the income should be treated as a dividend for purposes of section 116 and section 243.

A parallel situation in sections 305 and 306 of the Code offers a helpful analogy and suggests that receipt of sale income should not be treated as a dividend. ${ }^{46}$ Section 306 (a) provides that if preferred stock

44. 21 T.C. 625 (1954), nonacg., 1955-2 C.B. 11. A credit rather than a deduction was allowed to corporations under the 1939 Code for dividends received from domestic corporations. Int. Rev. Code of 1939, ch. 1, \& 26(b), 53 Stat. 1, 19.

45. See note 36 supra and accompanying text.

46. See note 39 supra. 
is sold, the amount realized is ordinary income to the extent that the shareholder would have received a dividend if, in lieu of the preferred stock, the corporation had distributed money equal to the preferred stock's fair market value at the time of distribution. The amount realized is treated as ordimary income, but sections 116 and 243 do not apply because section 306 does not treat the amount realized as a dividend distribution. The income is not received as a section 301 distribution from the corporation, but as the price paid by a third party for the stock.

The result is more probleinatical when analyzed in light of the objective of sections 116 and 243, which is to reduce the burdens of multiple taxation. Because neither section applies to the purchaser of a right, if the selling shareholder were allowed to use section 116 or section 243 , there would be no double use of these exclusions from income. This result suggests that from a policy standpoint it would be appropriate to allow the selling shareholder to apply section 116 or section 243 . On the other hand, if the purchaser failed to exercise the right, the corporate earnings that would have been distributed upon exercise would still be retamed by the corporation. These retamed earnings could later be distributed as a dividend to the shareholder who sold the right, and the shareholder could then apply section 116 or section 243 to the distribution. To allow the shareliolder to apply section 116 or section 243 when the right is sold and again when the retained earnings are actually distributed by the corporation would yield a double exclusion to the shareholder, a result clearly not in keeping with the purposes of those sections. Since the exercise is more likely than is a lapse by the purchaser of the option or right, the more logical policy result may be to allow use of section 243 and section 116 by a shareholder when a right is sold.

In summary, an analysis of the characterization of the proceeds from the sale of a right suggests that these proceeds do not represent dividend income for purposes of section 116 and section 243; nevertheless, the objective of these sections to avoid multiple taxation suggests that they ought to apply to a sale transaction.

5. Tax Consequences to the Distributing Corporation. Under Palmer, no distribution occurs until the exercise of the right; therefore, no tax consequences occur to the distributing corporation until that time. On the date of exercise, the corporation will be treated as having made a part sales transaction (to the extent of the option price) and a part dividend transaction (to the extent of the spread between the option price and the fair market value of the portfolio stock). The distrib- 
uting corporation has no tax consequences as a result of the sale or the lapse of a stock right, since the corporation is deemed under Palmer to have made no distribution until the right is actually exercised. ${ }^{47}$

Any gain or loss $^{48}$ recognized on the sales portion of the transaction will imcrease or decrease, respectively, the current earnings and profits of the distributing corporation. ${ }^{49}$ Normally, the earnings and profits are not separately reduced by the corporation's adjusted basis in the portfolio stock sold pursuant to the rights offering, because that basis is allocated entirely to the sales portion and none is allocated to the dividend portion of the transaction. ${ }^{50}$ The only exception to this gen-

47. Since under Palmer the time of the distribution is the date of exercise, the tax consequences to the corporation occur on that date. If a shareholder sells his right, he is treated as having received an anticipation of income even though the actual underlying property is not distributed by the corporation until the purchaser exercises the right. Consequently, any tax cousequences to the corporation, such as recognitiou of gain on the sales portion of the transaction or reduction of earnings and profits as a result of the distribution, do not occur until the purchaser exercises the right. For purposes of determining the consequences to $X$ 's earnings and profits, it is irrelevant that neither the sale of the right by a shareholder nor the exercise of the right by the purchaser is, from their standpoint, a dividend distribution by $X$. For example, if $M$ (an individual) were to sell to $R$ a right to a cash dividend from Corporation $X$, the proceeds of the sale would be ordinary incoine to $M$ under the anticipation of income doctrine; the distribution to $R$ would be a return of his capital to the extent of his purchase price, and ordinary income (but not dividend income) to the extent of the excess of the cash dividends over the purchase price. The cash distribution to $R$ would reduce $X$ 's earnings and profits under section 312 to the extent of the distribution. Thus, when the purchaser exercises the right, the corporation then determines whether it has recognized a gain or loss on that exercise, and earnings and profits will be adjusted accordingly for both the sales part and the distribution part of the transaction.

48. The discussion in note 52 infra suggests that the corporation not be allowed to recognize a loss as a result of selling corporate property to a shareholder for less than the corporation's adjusted basis in the property.

49. $\S 312(\mathrm{f})$.

50. See Treas. Reg. § 1.301-1(j) (1979); Treas. Rcg. § 1.301-1(k), Ex. 1 (1974). Sectiou 312(a)(3) requires that the earnings and profits of the corporation be reduced by the adjusted basis of any property distributed by a corporation to its shareholders with respect to its stock.

In the part sale, part gift transaction, the entire basis of the property is allocated to the sales portion of the transaction. Treas. Reg. $\$ 1.1001-1(\mathrm{e})(1972)$. By analogy, in the part sale, part dividend transaction, the entire basis would be allocated to the sales portion. The only instance of allocation of basis in a transaction characterized as composed of two parts is the legislatively mandated allocation of basis in a part sale, part charitable contribution transaction. $\$ 1011$ (b).

Notwithstanding the long history of allocation of basis entirely to the sales portiou, see, e.g., Reginald Fincke, 39 B.T.A. 510 (1939), the Sixth Circuit in Honigman v. Commissioner, 466 F.2d 69 (6th Cir. 1972), held that in a part sale, part dividend transaction, the distributing corporation's adjusted basis in the property should be allocated pro rata, in accordance with the ratio of the anount of distribution and of the purchase price to the total fair inarket value of the property, between each part of the transaction. The following example is based on the facts of Honigman. The mathematical calculations are those of the author.

Example: The adjusted basis of Corporation $X$ in a building was $\$ 1,486,000$ and the fair market value of the building was $\$ 830,000$. $X$ sold the building to one of its shareholders for $\$ 661,000$. Under Honigman, the basis must be allocated between the sales portion and the dividend portion as follows: 
eral conclusion occurs when the distributing corporation's adjusted basis in the portfolio stock is greater than the option price of the stock. In this circumstance the distributing corporation's earnings and profits must be reduced to the full extent of the excess of the corporation's adjusted basis over the option price. ${ }^{51}$ The footnote contains illustrations of the tax consequences to the distributing corporation under varying relationships of the option price to the fair market value of the stock and to the corporation's adjusted basis in the distributed stock. In every instance the option price is less than the fair market value of the stock so that the spread is treated as a dividend distribution upon the exercise of the right. ${ }^{52}$

$\begin{array}{lll}\text { Sales portion: } & \begin{array}{l}\text { Consideration } \\ \text { Fair Market Value }\end{array} & \times \text { Adjusted Basis }= \\ & \frac{\$ 661,000}{\$ 830,000} & \times \$ 1,486,000=\$ 1,183,429 . \\ \text { Dividend portion: } & \frac{\text { Amount of Distribution }}{\text { Fair Market Value }} & \times \text { Adjusted Basis }= \\ & \frac{\$ 169,000}{\$ 830,000} & \times \$ 1,486,000=\$ 302,571 .\end{array}$

The loss recognized on the sales portion is $\$ 522,429$, the excess of the allocated adjusted basis of $\$ 1,183,429$ over the sales price of the building of $\$ 661,000$. See note 52 infra, which discusses whether any loss should ever be recognized in a part sale, part dividend transaction. $X$ 's current earnings and profits are reduced by the loss recognized on the sales transaction. $\S 312(f)$. They are also reduced by the adjusted basis allocated to the dividend portion. $\S 312(\mathrm{a})(3)$. If a corporate shareholder purchases the building, the amouut of the distribution under section $301(b)(1)(B)$ is $\$ 169,000$, the lesser of the fair market value of the distribution $(\$ 169,000)$ and $X$ s adjusted basis in the property distributed as a dividend (the allocated basis of $\$ 302,571$ ).

Under the allocation method required by Honigman, the total reduction in earnings and profits is the same as the reduction in earnings and profits if the basis is allocated entirely to the sales portion of the transaction. The important effect of the allocation required by Honigman is to reduce the basis allocated to the sales portion, which, in turn, reduces the amount of recognized loss on the sales portion of the transaction and the amount of the reduction in current earnings and profits under section 312 (f).

51. Treas. Reg. § 1.301-1(j) (1979). See W.G. Maguire \& Co., 20 T.C. 20,40 (1953). When property is distributed froin a corporation to its shareholders, in order to reflect the fact that the unrecovered investment of the corporation in the property has been distributed to the shareholders, the corporation's earnings and profits are reduced by any adjusted basis not recovered by payment for the property. See $\$ 312(a)(3)$.

52. The following hypotheticals illustrate the tax consequences to the distributing corporation.

1. Option Price Exceeds Corporation's Adjusted Basis in the Stock. Corporation $X$ purchases stock in Corporation $Y$ for $\$ 2$ per share. When the fair market value of the $Y$ stock is $\$ 10$ per 
6. Tax Consequences to Shareholders When Earnings and Profits Are Insufficient to Cover the Spread. ${ }^{53}$ In W.G. Maguire \& Co. ${ }^{54}$ Corporation $X$ had acquired the stock of Corporation $Y$ at a cost of

share, $X$ distributes to its shareholders the right to purchase the $Y$ stock at $\$ 5$ per share. An individual shareholder exercises the right and pays $\$ 5$ to $X$. The excess of the option price of $\$ 5$ over $X \mathbf{s}$ adjusted basis of $\$ 2$ is gain on the sales part of the transaction. $X$ 's current earnings and profits are increased by the $\$ 3$ gain, $\S 312(\mathrm{f})$, and are decreased as a result of any income tax liability associated with that gain. The dividend distribution is $\$ 5$, the spread between the fair market value of $\$ 10$ and the option price of $\$ 5$. This distribution causes no adjustment to $X$ s earnings and profits because $X$ s $\$ 2$ basis in the $Y$ stock is allocated entirely to the sales portion of the transaction. See Treas. Reg. $\S 1.301-1(j)$ (1979).

Note that if a corporate shareholder exercised the right, the amount of the dividend distribution under the 1954 Code would be zero, since under $\$ 301$ (b)(1)(B) the amount of the distribution is the lesser of its fair market value (\$5) or the distributing corporation's adjusted basis in the property distributed (which is zero since X's entire basis was allocated to the sales portion).

2. Option Price Is Less Than Corporation's Adjusted Basis in the Stock. Corporation $X$ purchases stock in Corporation $Y$ for $\$ 7$ per share. When the fair market value of the $Y$ stock is $\$ 10, X$ distributes to its shareholders the right to purchase the $Y$ stock at $\$ 5$ per share. An individual shareholder exercises the right and pays $\$ 5$ to $X$. The dividend distribution is $\$ 5$, the spread between the fair inarket value of $\$ 10$ and the option price of $\$ 5$. $X$ recognizes neither gain nor loss on the transaction. This result is inferred from the example in Treas. Reg. $\S 1.301-1(\mathrm{k})$, Ex. 1 (1971), which contains a factual pattern similar to this hypothetical. It is also inferred by comparison with the exainples in the regulations concerning part sale, part gift transactions, in which a donor in a sinilar factual pattern recognizes neither gain nor loss. Treas. Reg. $§ 1.1001-1(\mathrm{e})(2)$, Ex. 2 (1972). On the one hand, the corporation should not be treated as having realized a $\$ 2$ loss (the excess of the adjusted basis of $\$ 7$ over the option price of $\$ 5$ ) because it suffers no real economic loss; rather, it creates an artificial loss by setting the option price below the adjusted basis and using the spread between the fair market value and the option price as a dividend distribution (that is, it uses this economic value for the payment of dividends). On the other hand, it should not realize a gain (the excess of the fair inarket value of $\$ 10$ over its adjusted basis of \$7) because it receives no consideration from the shareholder and thus reahizes no economic gain. See also \$311(a) (a corporation realizes neither gam nor loss as a result of making a distribution to its shareholders). $X$ s earnings and profits decrease by $\$ 2$, the difference between $X$ 's adjusted basis of $\$ 7$ and the amount received pursuant to the exercise of the option, \$5. See Treas. Reg. $\$ 1.301-$ 1(j) (1979) (earnings and profits are always reduced by the excess of the corporation's basis over the amount received for the distributed property).

Note that if a corporate shareholder exercises the right, the dividend under the 1954 Code is the lesser of the fair market value or the adjusted basis of the $Y$ stock over the option price. Treas. Reg. $\$ 1.301-1(j)$ (1979); Treas. Reg. $\$ 1.301-1(\mathrm{k})$, Ex. 1 (1971). In this example, the amount of the distribution to a corporate shareholder would be $\$ 2$, the excess of $X$ 's adjusted basis of $\$ 7$ over the option price of $\$ 5$.

3. Option Price Is Less Than the Fair Market Value of the Stock, and the Fair Market Value of the Stock Is Less Than the Corporation's Basis Therein. Corporation $X$ purchases stock in Corporation $Y$ for $\$ 12$ per share. When the fair market value of the stock is $\$ 10, X$ distributes to its shareholders the right to purchase the $Y$ stock at $\$ 5$ per share. An individual shareholder exercises the right and pays $\$ 5$ to $X$. The excess of $X$ s adjusted basis of $\$ 12$ over the fair market value of the $Y$ stock of $\$ 10$ yields a realized loss of $\$ 2$ on the sales part of the transaction. If the analysis of Honigman is applied, see note 50 supra, then $X$ 's adjusted basis of $\$ 10$ in the $Y$ stock must be allocated pro rata between the sales and dividend parts of the transaction. Simce the option price is $\$ 5$ and the dividend is $\$ 5$, the adjusted basis of $\$ 6$ is divided evenly between the two transactions. The excess of the allocated adjusted basis of $\$ 6$ over the option price of $\$ 5$ yields a realized loss of $\$ 1$ on the sales transaction.

Whether the loss is calculated to be $\$ 2$ or $\$ 1$, the deductibility of the loss for tax purposes is 
$\$ 47.86$ per share. $X$ issued to its shareholders rights to buy the $Y$ stock at $\$ 30$ per share, and on the date of issuance the fair market value of

uncertain; and even if a loss deduction is permissible, the allowance of the deduction may depend upon section 267. See Honigman v. Commissioner, 466 F.2d 69 (6th Cir. 1972) (if the purchase price paid by a shareholder is less than both the corporation's adjusted basis and the fair market value of the distributed property, and the fair market value is also less than the adjusted basis, then the corporation recognizes a deductible loss equal to the difference between the adjusted basis allocated to the sales part of the transaction and the sales price). But see W.G. Maguire \& Co., 20 T.C. 20, 36 (1953) (loss reduces the current earnings and profits of the distributing corporation but may not be deducted in computing taxable income).

The part sale, part gift regulations suggest, by analogy, that the corporation should never be allowed to recognize a loss for tax purposes when it essentially "gives away" its investment in the property to its shareholder through a bargain purchase. See Treas. Reg. \$1.1001-1(e)(2), Ex. 4 (1972) (when the adjusted basis of the property was $\$ 9$, the fair market value of the property was $\$ 6$, and the price paid by the donee was $\$ 3$, the difference between the price paid and the fair market value of the property was a gift, and the donor recognized no loss on the transaction). Thus, in any gift situation, to the extent the donor does not recover his mvestment (his basis) in the property, he does not recognize a loss. This result may be justified im part by a carryover of the donor's basis into the hands of the donee. $\$ 1015$; Treas. Reg. $\$ 1.1015-4$ (a), (b), Ex. 4 (1972). It must be noted, however, that the excess of the carryover basis over the fair market value of the property at the time of the gift is not useable by the donee unless the asset subsequently appreciates in value in the hands of the donee, and then it is useable only to the extent of that appreciation. See $\$ 1015$ (a) (if the donor's basis is greater than the fair market value of the property at the tine of the gift, then for purposes of determining a loss on the subsequent disposition of the propcrty by the donee, the basis of the property is its fair market value at the time of the gift, and not the donor's adjusted basis).

In the case of a bargain sale to a shareholder, however, the shareholder's basis in the property is always equal to the sum of the option price and the amount of the dividend distribution. In this exainple that sum is $\$ 10$, which is also the fair market value of the property. That the basis of the shareholder is not $\$ 12$, i.e., a carryover of the corporation's basis, does not mean, however, that the argument is fallacious. In the usual situation of a distribution in kind without the payment of consideration by the shareholder, the distributing corporation realizes no loss if its basis im the property exceeds the fair market value of the property at the time of the distribution, $\$ 311$ (a), and the shareholder has a basis in the distributed property equal to the fair market value of the property. $\$ 301$ (d). If a shareholder pays for the property, so that the amount of the dividend is less than the full fair market value of the property, the result should not change: the corporation realizes no loss when it makes a dividend distribution. On the other hand, the following example cautions against a dogmatic conclusion. Assume $X$ did not make a bargain sale of the $Y$ stock for $\$ 5$ to its shareholder, but instead sold one-half of the share of $Y$ stock to the shareholder at its fair inarket value of $\$ 5$. Since no bargain element exists in this sales transaction, the shareholder does not receive a dividend, and $X$ clearly realizes a $\$ 1$ loss that is deductible unless disallowed by section 267. After making the sale, $X$ then distributes the remaining one-half share of $Y$ as a dividend distribution. Even though $X^{\prime}$ 's adjusted basis exceeds the fair market value of this onehalf share of $Y, X$ is not allowed a $\$ 1$ loss. $\$ 311($ a). Thus, in this example, $X$ is allowed a $\$ 1$ loss if $X$ sells one-half of the $Y$ share for its fair market value and distributes the other one-half as a dividend. Why should $X$ be allowed a $\$ 1$ loss deduction in this situation, but disallowed a loss deduction for a bargain sale of the entire share at $\$ 5$ ? A justification for this difference in result does not spring to mind. Nevertheless, the same question (and example) can be posed in the part sale, part gift transaction, and it has been long established by admimistrative practice and by regulations that no loss is ever allowed in that situation. See, e.g., Treas. Reg. $\$ 1.1001-1(\mathrm{e})(1)(1972)$. One possible justification for the disallowance of any loss deduction in the part sale, part gift transaction may be the administrative difficulty in valumg the correct amount of the loss when there has been no arm's-length, commercial transaction by which the loss can be reliably mea- 
the stock was $\$ 40$ per share. The offering provided that for every share of $X$ stock owned, the shareholder could purchase one-tenth share of $Y$; therefore, ten rights were required to purchase a single share of $Y$ stock, and each right had a value of $\$ 1$. At the time of the rights offering, $X$ had a deficit in accumulated earnings and profits. It had positive current earnings and profits before adjusting for the stock sale at a loss, irrespective of incoine tax consequences to the corporation resulting from that sale.

As to $X$, the court concluded that the exercise of a right should be treated as a part sale, part dividend transaction. The difference between the cost of $\$ 47.86$ per share and the fair market value of $\$ 40$ per share represented a transaction similar to a sale; therefore, $X$ realized a loss of $\$ 7.86$ per share of $Y$ stock..$^{55}$ This anount was deducted in determining $X$ 's net income and current earnings and profits available

sured. If the donor were allowed a loss deduction in these situations, it normally would be based-except in the case of inarketable securities-on the taxpayer's possibly self-serving assessment of the fair market value of the property. The difficulty of verifying that assessment creates a potential tax avoidance, sufficient perhaps to suggest that in this instance the allowance of any loss deduction should be denied. This same justification can be applied to the part sale, part dividend transaction in which there also is no arm's-length, commercial transaction and no rehiable and objective measurement of the loss.

Note that if the shareholder is a corporation, the amount of the dividend distribution under the 1954 Code is the lesser of the fair market value or the adjusted basis of the $Y$ stock over the option price. Treas. Reg. $\$ 1.301-1(j)$ (1979). Applied to this example, the amount of the distribution to a corporate shareholder is $\$ 5$, the excess of the fair market value of the $Y$ stoek of $\$ 10$ over the option price of $\$ 5$. $X$ 's earnings and profits are reduced by $\$ 7$, the excess of $X$ 's adjusted basis in the $Y$ stock of $\$ 12$ over the option price of $\$ 5$. Id.

53. See note 4 supra, which describes the statutory structure pursuant to which the tax consequences of distributions to shareholders are determined. In particular, to determine whether a distribution is a "dividend" under section 316, distributions within a taxable year are deemed first to be a distribution of current earnings and profits for that taxable year. For this purpose, current earnings and profits are calculated at the end of the taxable year without regard to any distributions made during the taxable year. If current earnings and profits are less than the total amount of distributions unade during the taxable year, the current earnings and profits are allocated pro rata over each distribution. If total distributions during the taxable year exceed the current earnings and profits for that year, the excess of the distribution' over current earnings and profits is next treated as a distribution of accumulated earnings and profits available on the date of each distribution. Thus, accumulated earnings and profits are applied in chronological order to each distribution made during the taxable year. Treas. Reg. \$ 1.316-2(a), (b), (c), Ex. (1955).

54. 20 T.C. 20 (1953).

55. The court specifically held that the realized loss of $\$ 7.86$ reduced $X$ 's current earnings and profits, but it did not consider whether $X$ could deduct that loss. In dictum, however, the court stated that the losses could not be deducted in computing $X$ 's taxable income for that taxable year. 20 T.C. at 36. In Honigman v. Commissioner, 55 T.C. 1067 (1971), affd in part and rev'd in part, 466 F.2d 69 (6th Cir. 1972), the Tax Court lield such a loss deductible by the distributing corporation. But see example 3, note 52 supra (loss should not be deductible for tax purposes). Holding the loss not deductible does not mean, however, that the loss should not reduce current earnings and profits. Clearly, it should reduce current earnings and profits because that loss repre- 
for dividends. The loss created a deficit in $X$ 's current earnings and profits, so that if the exercise of the rights was a corporate distribution, it could not be taxed as a dividend.

The court next determined that since the option price was $\$ 30$ and the fair market value of the $Y$ stock was $\$ 40$ on the date of issuance, $X$ intended to make a distribution to its shareholders. The actual fair market value of the $Y$ stock on the date of exercise was greater than $\$ 40$; therefore, under the "lesser of" Choate rule, the amount of the distribution was limited to the $\$ 10$ spread on the date of issuance. Since $X$ had no accumulated earnings and profits at the time of exercise, and no current earnings and profits at the end of the taxable year in which the rights were exercised (after taking into account the $\$ 7.86$ loss per share sold), the $\$ 10$ distribution was treated as a return of capital. The basis in $X$ shares of shareholders who exercised a right was reduced by $\$ 10$ for each share of $Y$ stock received.

The court also had to determine the tax consequences of a sale of the right itself when the corporation had no earnings and profits. The court noted that according to Palmer no taxable event occurred upon the issuance of the option, but upon the sale of the option, the shareholder anticipated the distribution that would have been received had the option been exercised. Since the tax consequence of exercise was the return of $\$ 10$ of capital, the court concluded that the sale of the right also yielded a return of capital of $\$ 1$ per right. Therefore, for purposes of determining the amount of the shareholder's gam or loss on the sale of the right, the shareholder's basis in the right was $\$ 1$. Presumably, under this analysis the shareholder's basis in the $X$ stock was reduced by $\$ 1$, and any gain or loss recognized on the sale of the rights was a capital gain or loss. ${ }^{56}$

sents an investment by the corporation that will never be recovered, since it has transferred ownership of the property to its shareholders.

Based upon the Sixth Circuit's opinion in Honigman, the loss deduction under the facts of Maguire would be $\$ 5.90$ per share rather than $\$ 7.86$ per share. As discussed in note 50 supra, the court in Honigman required that in a part sale, part dividend transaction, the corporation's basis in the property be divided between the sale and dividend portions of the transaction. Since the option price in Maguire was $75 \%$ of the fair market value of the stock, $75 \%$ of the basis of $\$ 47.86$ (that is, $\$ 35.90$ ) is allocated to the sales transaction. The excess of the allocated basis over the option price (\$5.90) is treated as the loss realized by the corporation and is the amount by which the earnings and profits of the corporation are reduced for each share sold.

56. The right in the hands of the shareholder was a capital asset, the holding period for which would begin on the date of distribution or the date the shareholders received the right. Therefore, under the current capital gains statutory provisions, if the right were sold within one year of either date, the gain realized on the sale would be a short-term capital gain. See Gibson v. Commissioner, 133 F.2d 308 (2d Cir.) (any amount received by shareholder on sale of a right in excess of spread on date the right was distributed is taxed as a capital gain), appeal dismissed, 320 U.S. 805 (1943), and text accompanying notes 35-42 supra. 
The court's analysis is arguably incorrect. Under Palmer, no distribution from the corporation occurs until a right is exercised. Therefore, the distribution of a right in this instance cannot itself be a distribution of capital, since distribution of capital occurs only when the right is exercised. Bccause the distribution of the right is neither a taxable event nor a distribution of capital, the shareholder has no basis in the right, and all of the ainount realized on the sale of the right is taxable incoine. Under Gibson, because the shareholder would have received no ordinary income upon the exercise of the right, the proceeds from the sale of the right presumably are treated as a capital gain. If the corporation still has no earnings and profits on the day the purchaser exercises the right, then and only then is a distribution of capital made. ${ }^{57}$

No cases are reported that discuss the tax consequences of the sale and exercise of rights when there are some earnings and profits, but not enough to cover the total amount of distributions. The footnote con-

57. Finally, the Maguire court discussed the amount to be charged to earnings and profits because of the rights offering. It determined first that since the cost of the $Y$ stock to $X$ was $\$ 47.86$ per share, and each $X$ shareholder paid $\$ 30$ per share, the total amount of the reduction in earnings and profits resulting from the distribution was $\$ 17.86$. See Treas. Reg. $\$ 1.301-1(j)$ (1973). In every section 301 distribution, the corporation's earnings and profits should be reduced by the amount the corporation invests in the distributed property that is not recovered through the shareholder's subsequent payment for the property. This reduction in earnings and profits correctly ineasures the extent to which the corporation has transferred after-tax dollars out of the corporation into the hands of the shareholders. See \$312(a)(3) (earnings and profits must be reduced by corporation's adjusted basis in the property distributed to its shareholder).

In Maguire, the reduction was divided into two portions. First, the realized loss of $\$ 7.86$ was charged directly to net income and reduced current earnings and profits, in this instance creating a deficit in earnings and profits. This reduction in current earnings and profits then became a reduction in accumulated earnings and profits as of the first day of $X$ s next taxable year. Second, $X \mathbf{s}$ accumulated earnings and profits were reduced by the additional $\$ 10$ investment not recovered by the option price, that is, the $\$ 10$ spread between the fair market value of the $Y$ stock and the option price. This loss was not a reduction in current earnings and profits because it did not represent an economic loss, but a decision to distribute that $\$ 10$ to the shareholders without receipt of consideration. See §311(a) (a corporation in general realizes neither a gain nor a loss as a result of a section 301 distribution of property to a shareholder). This statute codifies the holding in General Utils. \& Operating Co. v. Helvering, 296 U.S. 200 (1935), that the payment of a dividend resulted in no taxable income to the distributing corporation because the corporation received nothing of value from the shareholder in exchange for the property distributed. Thus, the corporation could not have realized any economic gaim or loss as in a nornal sales transaction.

The $\$ 10$ distribution in Maguire did not reduce current earnings and profits, but it did reduce accuunulated earnings and profits because it represented an investment, made by $X$ in the $Y$ stock, which had left the corporation when distributed to $X$ shareholders. Nevertheless, in this instance, the $\$ 10$ did not reduce $X$ 's accumulated earnings and profits. As of the time of the rights offering, $X$ had a deficit in accuunulated earnings and profits, and that deficit could never be increased by a corporate distribution. Section 312(a) provides that the earnings and profits of a corporation are reduced only "to the extent thereof" as a result of a distribution of property by a corporation to its shareholders, an appropriate result in Maguire since the $\$ 10$ distribution was in fact not treated as a distribution from earnings and profits, but rather as a distribution from capital. 
tains three examples of the manner in which this situation should be handled based on the Palmer principles and the current definition of a "dividend" under section 316.58

58. Example 1: Corporation $X$ has a deficit in accumulated earnings and profits and has current earnings and profits of $\$ 100,000$. Pursuant to a rights offering, 20,000 rights are distributed and cxercised. The amount of each imdividual distribution is $\$ 10$. The current earnings and profits are less than the total amount of distribution $(\$ 200,000)$; consequently, current earnings and profits are allocated to each distribution in the ratio of each distribution to the total amount of all distributions. Treas. Reg. $\$ 1.316-2$ (b) (1955). Five dollars of each $\$ 10$ distribution are covered by current earnings and profits and in turn are taxed as a dividend under section 301(c)(1), while the remaining $\$ 5$ of the distribution are treated as a return of the shareholder's basis in the $X$ stock.

Assume the sane facts except that 15,000 distributions of $\$ 10$ are made through the exercise of rights, and 5,000 rights are sold for $\$ 10$. If the 5,000 rights that are sold had instead been exercised on the dates of sale, the spread and therefore the amount of the distribution on those dates would be $\$ 10$ with respect to each right. The purchasers exercise all 5,000 of the rights, and the spread with respect to each exercised right is also \$10. How are the current earnings and profits allocated to determine the tax consequences to the shareholders who exercise and sell rights? The income anticipated from the sale is deemed to equal the amount that would have been distributed had the right been exercised on the date of the sale, or \$10. But see text accompanying note 39 supra, which suggests as an alternative the date of issuance. To determine the portion treated as an anticipation of ordinary income, the $\$ 100,000$ of current earnings and profits are first allocated pro rata over the 5,000 rights that are sold and the 15,000 rights that are exercised, in the following manner:

Amount of distributions anticipated through sale of rights

Amount of distributions anticipated through sale of rights + amount of distributions made through exercise of rights

$\times \begin{aligned} & \text { Current } \\ & \text { earnings } \\ & \text { profits }\end{aligned} \quad=\begin{aligned} & \text { Amount of current } \\ & \text { earnings and profits } \\ & \text { allocated to rights }\end{aligned}$

5,000 rights sold $\times \$ 10$ anticipated distribution per right sold

$(5,000$ rights sold $\times \$ 10$ anticipated distribution per right sold $)+(15,000$ rights exercised $\times \$ 10$

$\$ 25,000$ current $=$ earnings and profits allocated to rights sold spread on date of exercise)

Since $\$ 5$ of earnings and profits are allocated to every right sold $(\$ 25,000$ current earnings and profits $/ 5,000$ rights sold $=\$ 5$ per right), $\$ 5$ of the sales proceeds are treated as the anticipation of ordinary income, and the remaining $\$ 5$ are taxed as a short-tcrun capital gain. To determine the tax consequences to shareholders who exercise their rights, current earnings and profits are allocated pro rata over the 15,000 rights that are exercised by the shareholders and the 5,000 rights that are exercised by the purchasers in the following manner:

Amount of distributions made through exercise by shareholders of rights

Amount of distributions made through exercise by shareholders of rights + anount of distributions made through exercise by purchasers of rights

$\times \begin{aligned} & \text { Current } \\ & \text { earnimgs } \\ & \text { and }\end{aligned} \quad \begin{aligned} & \text { Amount of current } \\ & \text { earnings and profits } \\ & \text { allocated to rights } \\ & \text { exercised by share- } \\ & \text { holders }\end{aligned}$




\section{Critique of the Judicial Development. The Palmer principles}

15,000 rights exercised by shareholders $\times \$ 10$ spread on date of exercise

$(15,000$ rights exercised by shareholders $\times \$ 10$ spread on date of exercise $)+(5,000$ rights exercised by purchasers $\times \$ 10$ spread on date of exercise)
$\$ 75,000$ current earnings and profits

$\times \$ 100,000$
$=$ allocated to rights exercised by shareholders

Since $\$ 5$ of current earnings and profits are allocated to each right exercised by a shareholder $(\$ 75,000$ curreut earnings and profits $/ 15,000$ rights exercised $=\$ 5$ per right), each shareholder who exercises a right has $\$ 5$ of divideud incone, and the remaining $\$ 5$ reduce his basis in his $X$ stock. The purchasers of the rights have no tax consequences as a result of exercising the rights.

Example 2: Corporation $X$ has current earnings and profits of $\$ 100,000$ and accumulated earnings and profits of $\$ 200,000$. Pursuant to a rights offering, 40,000 rights are distributed and exercised. The anount of each individual distribution is $\$ 10$; therefore, total distributions are $\$ 400,000$. Current earnings and profits of $\$ 100,000$ are first allocated pro rata to each distribution, i.e., $\$ 2.50$ per distribution. Accumulated earnings and profits are next allocated to each distribution in chronological order. Treas. Reg. \$ 1.316-2(a), (b), (c), Ex. (1955). Thus, $\$ 7.50$ of accumulated earnings and profits are allocated to each of the first 26,667 distributions, and the accumulated earnings and profits account is exhausted. The total earnings and profits of $\$ 10$ allocated to each of the first 26,667 distributions are taxed as a dividend. The renaining 13,333 distributions are taxed as a dividend distribution of $\$ 2.50$ and a $\$ 7.50$ return of the shareholder's basis in the $X$ stock.

Assume the same facts exccpt that 20,000 distributions of $\$ 10$ are made through the exercise of rights and 20,000 rights are sold for $\$ 10$. If the 20,000 rights that are sold had instead been exercised on the dates of sale, the spread and therefore the amount of the distribution on those dates would be $\$ 10$ with respect to each right. The purchasers exercise all 20,000 of the rights, and the spread with respect to each of these exercised rights is also $\$ 10$. How are the earnings and profits allocated to determine the tax consequences to the shareholders who exercise and sell rights? The amount of income anticipated from the sale is deemed to equal the amount that would have been distributed had the right been exercised on the date of the sale, or $\$ 10$. To determine the portion to be treated as an anticipation of ordinary income, current earnings and profits are allocated pro rata over the 20,000 rights that are sold and the 20,000 rights that are exercised, in the following unanner:

20,000 rights sold $\times \$ 10$ anticipated distribution per right sold

$(20,000$ rights sold $\times \$ 10$ anticipated distribution per right sold $)+(20,000$ rights exercised $\times \$ 10$ spread on date of exercise)

$\$ 100,000$
current
$\begin{aligned} & \text { earnings } \\ & \text { and }\end{aligned}$
profits $\quad \begin{aligned} & \$ 50,000 \text { current } \\ & \text { earnings and profits } \\ & \text { allocated to rights } \\ & \text { sold }\end{aligned}$

Since $\$ 2.50$ of current earnings and profits are allocated to every right sold ( $\$ 50,000$ current earnings and profits $/ 20,000$ rights sold $=\$ 2.50$ ), $\$ 2.50$ of the sales proceeds are treated as the anticipation of ordinary income. Accumulated earnings and profits are next allocated to these same rights in chronological order, i.e., over the rights sold (using the date of sale) and the rights exercised by shareholders. Thus, $\$ 7.50$ of accumulated earnings and profits are allocated to each of the first 26,667 of these rights, sold or exercised, and the shareholders anticipate an additional $\$ 7.50$ of ordinary income upon sale of a right. Those rights that are sold and that fall within the last 13,333 rights by chronological order yield only $\$ 2.50$ of ordinary income and the remaining $\$ 7.50$ of the sale proceeds are taxed as a short-term capital gain. To determine the tax consequences to shareholders who exercise their rights, current earnings and profits are allocated pro rata over the 20,000 rights that are exercised by shareholders and the 20,000 rights that are exercised by the purehasers of the rights, in the following manner: 
have been the subject of consistent criticism by commentators ${ }^{59}$ who have referred to the present system of taxing stock rights as unnecessarily complicated. For example, under the Choate rule a taxpayer must know the spreads on both the issuance and the exercise dates because Choate limits the dividend distribution to the lesser of the two spreads. Even more complicated is the situation in which earnings and profits are insufficient to cover all of the distributions and therefore must be allocated pro rata over each distribution (and such distributions may vary in amount because the spreads may vary every day of the exercise period!). Also alarming is the allocation of accumulated earnings and profits in chronological order of distribution. Simce the various exercise dates determine the order of the distributions, the number and amount of distributions must be determined for each date during the option period and placed in chronological order. The dividend consequences of the distributions may depend upon the fortuity of early or late exercise during the option period. This is the description of a system both unnecessarily complicated and arguably unfair.

Aside from questions of fairness and administrative complexity, the present system is economically unreahistic. It is based upon a statement of the Supreme Court in Palmer that the mere issuance of an

20,000 rights exercised by shareholders $\times \$ 10$ spread on date of exercise

$(20,000$ rights exercised by shareholders $\times \$ 10$ spread on date of exercise $)+(20,000$ rights exercised by purchasers $\times \$ 10$ spread on date of exercise)

$\begin{array}{ll}\$ 100,000 & \begin{array}{l}\$ 50,000 \quad \text { current } \\ \text { current }\end{array} \\ \times \text { earnings } & =\begin{array}{l}\text { allocated to rights } \\ \text { and } \\ \text { exercised by share- } \\ \text { profits }\end{array} \\ \text { holders }\end{array}$

$\$ 50,000$ current earnings and profits exercised by shareholders

Since $\$ 2.50$ of current earnings and profits are allocated to each right, each shareholder who exercises a right has $\$ 2.50$ of dividend incoine. The accunulated earnings and profits are next allocated over these same rights in chronological order, i.e., $\mathrm{m}$ accordance with the dates on which the rights are exercised. Seven dollars and fifty cents of accuinulated earnings and profits are allocated to the first 26,667 rights that are exercised by either shareholders or purchasers, and therefore yield an additional $\$ 7.50$ of ordinary incoine to the shareholders. No additional earnings and profits are allocated to those rights that are exercised by shareholders and that fall within the last 13,333 rights by chronological order, so that only $\$ 2.50$ of each of these distributions are taxed as a dividend and the reinaining $\$ 7.50$ are treated as a return of basis.

Example 3: Corporation $X$ has a deficit in both current and accunulated earnings and profits in Year 1. During that year, $X$ distributes rights to purchase $Y$ stock. Twenty thousand distributions of $\$ 10$ are made through the exercise of those rights in Year 2. In that year, $X$ has no aceumulated earnings and profits and has current earnings and profits of $\$ 40,000$. Since the distribution occurs in Year 2 when $X$ has current earnings and profits of $\$ 40,000, \$ 2$ of each distribution are treated as a dividend and $\$ 8$ of each distribution are treated as a return of basis.

59. E.g., Carlson, supra note 1, at 143; Lowndes, The Taxation of Stock Dividends and Stock Rights, 96 U. PA. L. REv. 147, 166-70 (1947); Sinith, supra note 1, at 477-83; Whiteside, supra note 1 , at 1023. 
option to purchase property is not a dividend because no distribution of property can occur until the option is exercised. ${ }^{60}$ This statement ignores the value of the option itself as intangible property. Moreover, many options when issued are freely transferable, may be very marketable, and in the case of stock rights, are frequently traded on the stock exchange. The Palmer dictum also overlooks the corporation's distribution of something valuable in the issuance of the option, which before the option had belonged solely to the corporation. For example, the shareholder upon issuance has the right to demand direct ownership of the property subject to the option, as opposed to continuing mdirect ownership of the property through his status as a shareholder. Frequently he obtains this right at a bargain price. Thus, on the date the option is issued the corporation has given up any interest in the spread on that date, and during the option period the corporation has given up the right to any interest in future appreciation and depreciation of the underlying property. Certainly Palmer is correct that the issuance of the option is not yet a distribution of the underlymg property, but it otherwise ignores certam property rights im the option that, prior to the option, the corporation alone possessed in association with ownership of the property subject to the option.

Based upon these arguments, commentators have concluded that it is appropriate to treat the issuance of the option as a distribution to the shareholder equal in amount to the value of the option on the date of its issuance. This tax system recognizes the economic reahty that the option itself is a valuable property right and also simplifies tax computations. That is, the amount of every distribution to every shareholder is the same-the value of the option-and every distribution is made on the same date-the date of issuance of the option.

Assuming that the arguments of the commentators are convincing-and they should be after reviewing the labyrinthian tax scheme that developed froin Palmer-can this sensible result be accomplished simply by an enlightened judicial opinion or revenue ruling, or is the language in Palmer so clear-that the distribution of property occurs only upon the exercise of an option-that this alternative scheme of taxation must be accomplished by expressly amending the Code? Several commentators have suggested that the 1954 Code provided just such an overruling of the Palmer principles. The next portion of this Article explores their suggestion and the judicial reaction to the proposition that, following the enactment of the 1954 Code, the Palmer principles are no longer vahd. 


\section{Development After the Enactment of the 1954 Code.}

1. Did the Enactment of the 1954 Code Overrule Palmer? The Palmer case was decided under the 1928 revenue statute, ${ }^{61}$ which defined a dividend as "any distribution made by a corporation to its shareholders, whether in money or in other property, out of its earnings and profits." ${ }^{2}$ The Palmer Court concluded that the issuance of an option did not constitute a distribution out of corporate profits, and so was not a dividend.

In 1954 the corporate tax provisions were substantially rewritten. The new Code treated stock dividends and stock rights to acquire the issuing corporation's own stock separately. Section 305 provided the general rule that the issuance of a stock dividend or a stock right to acquire the issuing corporation's own stock is not a taxable event, but it went on to list exceptions to this general rule. Any stock rights to acquire the issuing corporation's own stock that are not excluded from income under section 305 , any stock rights to purchase portfolio shares, and any other types of options issued to shareholders are to be taxed as distributions under section 301, which applies to distributions of property to shareholders. The word "property" is now defined in section 317 (a) to inean "money, securities, and any other property; except that such term does not include stock in the corporation making the distribution (or rights to acquire such stock)." $"$ " Although Congress did not spccifically address the taxation of options distributed to shareholders to purchase corporate property, the definition of "property" is certainly broad enough to include options. Commentators therefore have suggested that the 1954 definition of property can be interpreted as overriding the Palmer dictum that the issuance of an option is not a dividend distribution. One commentator has argued that since the definition of "property" specifically excludes the distribution of stock and stock rights of the issuing corporation, it must by negative inference mean to include the distribution of the stock of another corporation or rights to acquire the stock. ${ }^{64}$ Nothing in the legislative history supports or refutes this suggestion. ${ }^{65}$ In discussing the new definition of property, the legislative reports accoinpanying the 1954 Code do not mention stock rights of portfolio shares, the Palmer case, or in general the

61. Revenue Act of 1928, Pub. L. No. 70-562, 45 Stat. 791.

62. Id. $\S 115(\mathrm{a})$.

63. $\S 317(\mathrm{a})$.

64. Carlson, supra note 1, at 141-42.

65. See H.R. Rep. No. 1337, 83d Cong., 2d Sess. 35, A100, reprinted in [1954] U.S. CODE Cono. \& AD. News 4025; S. Rep. No. 1622, 83d Cong., 2d Sess. 252, reprinted in [1954] U.S. Code Cono. \& AD. News 4629. 
distribution of options to shareholders.

Another commentator has suggested, however, that the probable reason for the express exclusion of stock and stock rights of the issuing corporation from the definition of property was to prevent overlap or possible conflict with section $305 .{ }^{66}$ Without the express exclusion of section 317(a), one might have interpreted that section to require that all stock dividends and stock rights be taxed immediately upon distribution, rather than only those stock dividends and stock rights expressly made taxable under section 305 . Again, the legislative history is silent on this point, but the suggested interpretation is logical in hight of the separate treatment of stock dividends.

Because of the absence of legislative history suggesting an intent on the part of Congress to overrule Palmer or even to conclude, as one commentator did, ${ }^{67}$ that Palmer was overruled by negative inference, a determination that the 1954 Code overruled Palmer appears rather dogmatic. This conclusion is further supported by the fact that the Internal Revenue Service, following the enactment of the 1954 Code, did not administratively alter its practice of taxing options only upon their exercise. At least as late as 1961, the Commissioner of the Service ruled that the shareholder was taxed only upon exercise of an option. ${ }^{68}$ Moreover, the first reported case after Palmer in which the Government argued that the issuance of an option was taxable to the shareholder appeared in 1969,69 fifteen years after Palmer was supposedly "overruled" by the 1954 Code. The Service's continued application of the Palmer principles until long after the enactment of the 1954 Code suggests that neither Congress nor the executive branch had Palmer in mind when the dividend provisions were substantially revised. Further support for this conclusion is derived by examining the simultaneous development of the tax consequences of employee options, an evolution that ends with a result exactly contrary to the dictum in Palmer that the issuance of an option is not a taxable event.

2. Comparison of Developments in the Area of Employee Stock Options. The history of the taxation of einployee stock options has been discussed elsewhere ${ }^{70}$ and is not fully repeated here. Nevertheless, portions of that history present an interesting and helpful parallel

66. Smith, supra note 1 , at $474-75$.

67. Carlson, supra note 1, at 141-42.

68. Oscar E. Baan, 45 T.C. 71, 85 (1965) (private letter ruling, June 28, 1961).

69. Oscar E. Baan, 51 T.C. 1032 (1969).

70. E.g., B. Bittker \& L. Stone, Federal Income, Estate and Gift Taxation 54-56 (4th ed. 1972) \& 24-29 (1977 Supp.); 1 S. SurReY, W. Warren, P. McDaniel, \& H. Ault, FEDERAL InCOME TAXATION 1083-1100 (1972) \& 421-25 (1977 Supp.). 
to the taxation of options to shareholders. Only eight years after its decision in Palmer, the Supreine Court heard Commissioner v. Smith, ${ }^{71}$ its first case concerning the tax consequences to an employee when his corporate employer issued an option to purchase stock that it owned in another corporation. On the date the option was granted, the market value of the stock did not exceed the option price. When the employee exercised the options during the following two years, the purchase price of the stock was less than its fair market value. The Court determined that although no spread existed on the date of grant, the issumg corporation intended to compensate its employee through the spread that developed after that date. The spread was taxable incone under section 22(a) of the 1939 Code, ${ }^{72}$ which included in taxable income any economic or financial benefit conferred on the employee as coinpensation, whatever the form or inode by which it was effected. ${ }^{73}$

Now, compare the decisions of Palmer and Smith (both written, incidently, by Mr. Justice Stone). The Court held in Palmer that if no spread existed when the corporation decided to issue an option to its shareholders, the shareholders realized no income upon issuance or exercise of the option because the corporation could not have intended to make a dividend distribution. In Smith, the Court held that if no spread existed when the corporation issued an option to its employee, the spread on the date of exercise was nevertheless taxable as compensation income to the employee because the corporation had intended to use that spread to compensate the employee. Moreover, the Smith Court stated that in some circumstances it might find that the issuance itself was intended by the employer to be the compensation. Presumably such an intent might occur when a spread existed on the date of issuance, but this seems inconsistent with the Palmer dictum that only on the date of exercise does the corporation sever assets from corporate solution.

Since the economic effect of issuing an option, whether to employees or to shareholders, appears identical for both the corporation and the recipient, a comparison of these cases and their similar factual patterns leaves one puzzled. The apparently conflicting results might be rationalized by noting that the intent discussion in the decisions suggests that the Court relied upon lower court findings that the corporation intended a sale (and not a dividend) in Palmer but intended

71. 324 U.S. 177 (1945).

72. Pub. L. No. 76-1, \&22(a), 53 Stat. 1, 9, the predecessor provision to section 61(a) of the 1954 Code.

73. 324 U.S. at 181. 
compensation (and not a sale) im $S$ mith. ${ }^{74}$ This subjective factor may rationalize the results, but did the Court really mean to make the tax consequences of issumg options turn upon subjective intent? The Second Circuit thought not; rather, it stated in Choate $^{75}$ that the most important factor in determining intent is the presence or absence of a substantial spread on the date of issuance. This statement is troubling in light of the Smith opinion, which found the development of a subsequent spread evidence of an intent to compensate the employee.

In the alternative, the apparent inconsistencies in the two opinions might be rationalized by coinparing the relevant revenue statutes: in Smith the Court was interpreting the definition of gross income in section 22(a) of the 1939 Code, while in Palmer the Court was interpreting the dividend distribution portion of the revenue statute. The Court may have thought that the broad definition of gross imcome could encompass any econoinic benefit transferred to an employee, but in Palmer, notwithstanding the receipt of a valuable econoinic benefit (the option), the statute taxed shareholders only on distributions. No distribution occured within the meaning of the statute until the exercise of the option. This arguinent might also explain the lack of acknowledgment in Smith of the discussion in Palmer that no corporate property is distributed by the mere issuance of an option.

The Court decided its second employee stock option case, Commissioner v. LoBue, ${ }^{76}$ in 1956. An employer corporation had adopted in 1944 a stock option plan making 10,000 shares of its common stock available for distribution to key employees at five dollars per share over a three-year period. The first of three options granted to LoBue was nontransferable and contingent upon his continued employment until the date of exercise. The last two options were immediately exercisabie. LoBue exercised the options during 1946 and 1947. The Court did not state whether a spread existed between the option price and the fair market value of the stock on the date the option was granted; however, a spread did exist on the date the option was exercised. The Court had no trouble concluding that LoBue had received a financial benefit that was taxable as compensation incoine, but neinbers of the Court disagreed over the timing, for tax purposes, of the receipt of income. The majority noted that it was "of course possible for the recipi-

74. It is not, however, necessarily more likely that an offer to sell property to an employee will contain a form of compensation than that a similar offer made to a shareholder will contain a dividend distribution.

75. See text accompanying notes 26-30 supra.

76. 351 U.S. 243 (1956). 
ent of a stock option to realize an immediate taxable gain," 77 particularly when the option had "a readily ascertainable market value and the recipient might be free to sell his option."78 Agam, these comments were made without reference to the earlier Palmer decision. But the Court held that LoBue should be taxed on the spread at the time of exercise, since the options were not transferable and one of the rights was contingent upon his contimued einployment. ${ }^{79}$ Moreover, the Court noted the Treasury's practice of taxing stock options at the time an option is exercised. ${ }^{80}$ Two dissenting Justices would have held that compensation income was received when the second and third options were granted, because on that date the corporation conferred a benefit of substantial and immediately realizable value. The two Justices thought any other result inade the division of the total gains between ordinary income (that is, compensation) and capital gain (upon the subsequent sale of the stock) depend solely upon the timing of the exercise of the option. ${ }^{81}$

Dicta in both Smith and LoBue suggest that if an option has a readily ascertainable fair market value on the date the option is granted, the employee may have compensation income equal to the value of the option itself, but no case thereafter has held the receipt of an option taxable upon receipt. The Service did not acknowledge these dicta until 1961, when it amended its regulations to provide that if an option had a readily ascertainable fair market value at the time it was issued, the employee would immediately realize ordinary income equal to the value of the option..$^{82}$

In 1969, Congress enacted section 83, which provides explicit rules

77. Id. at 249.

78. $Y d$.

79. $r d$.

80. $Y d$.

81. Id. at 251 (Harlan and Burton, JJ., concurring in part and dissenting in part). The dissenting opinion gave the following example: Assune two einployees are given an option to purchase stock at $\$ 5$ per share, which at that time is also the fair market value of the stock. Employee $A$ cxercises the option immediately but realizes no compensation income because no spread exists on the date of exercise. $A$ later sells the stock when its fair market value is $\$ 15$ and realizes a capital gain of $\$ 10$ per share. Employee $B$, on the other hand, does not exercise his option until the stock has a fair market value of $\$ 15$ per share. The spread of $\$ 10$ upon the exercise of the option is thus taxed entirely to him as ordinary incone. Id. at 25l, n.2. This same caprieiousness occurs under the Palmer rules concerning the issuance of options to shareholders. First, the amount of the dividend (and, accordingly, the amount of ordinary mcome) depends upon a comparison of the spread on the date of issuance and the date of exercise of the option. Second, if earnings and profits of the corporation are insufficient to cover all of the distributions resulting from the options, the application of accumulated earnings and profits in chronological order yields ordinary income to those who exercise earliest and no tax consequenccs except a reduction in basis to those who exercise later, after earnings and profits have been depleted.

82. Treas. Reg. \& 1.421-6(c)(1) (1961). 
for determining the tax consequences of transferring property to an employee as compensation for services. Because options are property, section 83 applies to the issuance of options to employees. Section 83 taxes the employee upon the receipt of the option if on that date the option has a readily ascertainable fair market value and the option is transferable or not subject to a substantial risk of forfeiture. ${ }^{83}$ If the option is taxed when issued, there is no further tax consequence when the option is exercised. ${ }^{84}$ The regulations provide that an option has an ascertainable fair market value if it is actively traded on an established inarket. ${ }^{85}$ If the option is not actively traded, it is still considered to have an ascertainable fair market value if it can be measured with reasonable accuracy. ${ }^{86}$ If the option does not have an ascertainable fair

83. § 83(a), (e)(3),

84. $\S 83(\mathrm{e})(4)$.

85. Treas. Reg. \& 1.83-7(b)(1) (1978).

86. Treas. Reg. $\S 1.83-7$ (b)(2) (1978). This regulation provides that if an option is not actively traded when granted, then it has a readily ascertainable fair market value only if all the following conditions exist: (1) the option is transferable, (2) the option is exercisable immediately in full, (3) the option or the property subject to the option is not subject to any restriction or condition that has a significant effect upon the fair market value of the option, and (4) the fair unarket value of the option privilege is readily ascertainable in accordance with paragraph (b)(3) of this part of the regulations, which provides that the fair inarket value of an option is not merely the difference that may exist at a particular time between the option's exercise price aud the value of the property subject to the option, but also includes the value of the option privilege for the remainder of the exercise period. In determining whether the value of that privilege is readily ascertainable, it is necessary to consider the ability to ascertain the value of the property subject to the option, the probability that any ascertainable value of the property will increase or decrease during the option period, and the length of the period during which the option can be exercised. Treas. Reg. \& 1.83-7(b)(3) (1978).

The Service also has requested public comment on how a stock option can be valued with reasonable accuracy if it is not actively traded on an established market. 67 DAILY TAX REP. (BNA) G-1 (Apr. 5, 1979).

A substantial anount of economic and finance literature has been published concerning the valuation of stock options. See, e.g., Black \& Sholes, The Pricing of Options and Corporate Liabilities, 81 J. Political Econ. 637 (1973); Dimson, Instant Option Valuation, Financial Analysts J., May-June 1977, at 62; Samuelson, Rational Theory of Warrant Pricing, Indus. MANAGEMENT Rev. Spring 1965, at 13; Saunuelson \& Mertou, $A$ Complete Model of Warrant Pricing that Maximizes Utility, Indus. MANAGEMENT REv., Winter 1969, at 17; Shelton, The Relation of the Price of a Warrant to the Price of Its Associated Stock, Financial ANALYSTS J., May-June 1967, at 14351, and July-Aug. 1967, at 88-99; Van Horne, Warrant Valuation in Relation to Volatility and Opportunity Costs, INDUS. MANAGEMENT REv., Spring 1969, at 19. These writings illustrate that the important factors in the valuation of stock options include the fair market value of the stock, the exercise price, the time remaining before the lapse of the option, the volatility of the price of the stock, and the risk-free interest rate. For example, Professor Paul Samuelson shows mathematically that the value of the option increases proportionally with the square root of the time remaining before the lapse of the option. As that time approaches infinity, the value of the option approaches the value of the stock. Samuelson, supra. One empirical study of regularly quoted stock options showed the importance of the length of the option period. According to that study, when the exercise price equals the fair market value of the stock, and the remaining option period is at least two years, the value of the option is approximately $41 \%$ of the exercise price. As the 
market value when issued, the employee is not taxed until he exercises the option. ${ }^{87}$ These tax consequences are similar to the manner in which options would be taxed when issued to shareholders if the Palmer principles were no longer vahid.

The history of the taxation of options issued to employees lends support to the argument that the Palmer principles should no longer be considered valid. At the very least, the Court's opinions in Smith and LoBue raise questions about the soundness of the Palmer dictum that the issuance of an option is not a distribution taxable to the shareholder. If Palmer is distinguishable froin Smith and LoBue because the latter two cases involved an interpretation of the broad definition of gross incoine while Palmer concerned an interpretation of the more specific dividend distribution provisions, then the remaining question is whether the enactment of the 1954 Code substantially modified these distribution provisions so that the issuance of the option itself is a distribution of property within the meaning of those provisions. As discussed earlier, the evidence is at best inconclusive, but may be sufficient to enable a court to consider ignoring the Palmer decision.

Because no econounic justification exists for differentiating between options to employees and options to shareholders, the present system-taxation of employee options when issued-may at least encourage courts to interpret the dividend distribution provisions after the enactment of the 1954 Code to require that a shareholder be taxed under section 301 when he receives the option rather than when he exercises it. On the other hand, since the practice of taxing employee options on the date of exercise was not modified until $1961,{ }^{88}$ and the taxation of options upon their issuance was not given explicit congressional approval until $1969,{ }^{89}$ courts may be reluctant to modify the Palmer principles by judicial decision. They miglit determine that

option period decreases below two years, the value of the option decreases $1 / 24$ for each month less than two years. Presentation of the Investment Bankers Association of America to the Commissioner of Internal Revenue, Federal Income Taxation of Compensatory Options (mcluding Warrants) Granted to Underwriters and Other Independent Contractors (Oct. 8, 1963), discussed in Baumer v. United States, 580 F.2d 863, 882 n.27 (5th Cir. 1978), and Carlson, supra note 1, at 143 n.48.

87. Section 83(b) gives the employee the election to include in his gross income the value of property in the year received even though it would not otherwise be included in gross income for that year because it did not meet the requirements of section 83(a). For example, if an employee receives an option to purchase corporate property at a bargain price but that option would not be taxed under section 83(a) upon its receipt because it was not publicly traded, the employee may nevertheless elect under section $83(\mathrm{~b})$ to mclude $\mathrm{m}$ his gross imcome the value of the option in the year of its receipt.

88. See text accompanying note 82 supra.

89. See text accompanying notes 83-87 supra. 
those principles should continue to apply until Congress exphicitly provides, as it did with respect to einployee options, that the issuance of an option is a section 301 distribution.

3. Judicial and Administrative Treatment of the Issuance of Options. Since 1954, two important cases have been decided and one revenue ruling issued concerning the issuance of options to shareholders. The 1968 Supreine Court opimon in Commissioner v. Gordon ${ }^{90}$ is important both to this part of the Article and to Part III, which discusses the use of nontaxable stock rights. The second case, Baumer v. United States, ${ }^{91}$ was recently decided by the Fifth Circuit and is important for its review of the continuing validity of the Palmer principles. In addition, in 1970 the Service issued a revenue ruling that sets forth its current position concerning the taxation of the issuance of taxable options. ${ }^{92}$

(a) Commissioner v. Gordon. The factual discussion of this case is necessarily detailed and its judicial history is complicated because taxpayers residing in both the Second and Ninth Circuits litigated the same issues, yielding seven reported opinions. ${ }^{93}$

Pacific Telephone and Telegraph Coinpany (Pacific) was a subsidiary of American Telephone and Telegraph Company (A.T. \& T.), which owned about ninety percent of Pacific's stock. The remaining ten percent was widely held. Pacific provided comınunications services in California, Oregon, Washington, and Idaho. For business reasons it decided to separate into two corporations-one corporation would operate solely in California and the other would operate in the other three states. On June 30,1961, Pacific transferred all of its assets and liabilities related to operations im Oregon, Washington, and Idaho, to Pacific Northwest Bell Telephone Company (Northwest) in exchange for all of Northwest's stock and obligations. Pacific next planned to transfer enough Northwest stock to Pacific's shareliolders to pass control of

90. 391 U.S. 83 (1968).

91. 580 F.2d 863 (5th Cir. 1978).

92. Rev. Rul. 70-521, 1970-2 C.B. 72. See note 115 infra and text accompanying notes 114-16 infra.

93. The taxpayer who resided in the Ninth Circuit, Oscar E. Baan, was a party in the following decisions: Oscar E. Baan, 45 T.C. 71 (1965), rev'd sub nom., Commissioner v. Baan, 382 F.2d 485 (9th Cir. 1967), aff'd sub nom., Commissioner v. Gordon, 391 U.S. 83 (1968), on remand, Oscar E. Baan, 51 T.C. 1032 (1969), affd sub nom., Baan v. Commissioner, 450 F.2d 198 (9th Cir. 1971). The taxpayer who resided in the Second Circuit, Irving Gordon, was a party in the following decisions: Oscar E. Baan, 45 T.C. 71 (1965), affd in part and rev'd in part sub nom., Commissioner v. Gordon, 382 F.2d 499 (2d Cir. 1967), rev'd, 391 U.S. 83 (1968), on remand, Oscar E. Baan, 51 T.C. 1032 (1969), affd sub nom. Gordon v. Commissioner, 424 F.2d 378 (2d Cir. 1970). 
Northwest to A.T. \& T. In addition, Pacific wanted to distribute the Northwest stock in a manner that would raise cash to pay off certain existing liabihities and meet certaim needs for capital. Consequently, Pacific decided to distribute the Northwest stock through a rights offering. On September 30, 1961, Pacific distributed to its common sharehol'ders one Northwest right for each outstanding share of Pacific stock. These rights were exercisable until October 20, 1961, and covered about fifty-seven percent of the Northwest stock. Six rights plus the payment of sixteen dollars were required to purchase one share of Northwest stock; however, the sixteen dollar payment was less than the fair market value of the Northwest stock. Pacific's shareholders were advised at the time of the rights distribution that Pacific expected to offer the balance of the Northwest stock within about three years. On June 12,1963, the remaiming forty-three percent of the Northwest stock was offered to Pacific's shareholders. Under this offering, eight rights plus sixteen dollars were required to purchase one share of Northwest stock.

Pacific received a private ruling from the Internal Revenue Service on June 28, 1961, that the shareholders who sold rights would realize ordinary incoine in the ainount of the sales price, and that shareholders who exercised rights would realize ordinary income in the amount of the difference between the sixteen dollars paid and the fair market value of the Northwest stock on the date of exercise. ${ }^{94}$ This ruling was consistent with the judicial developments after Palmer and did not imdicate that the Service thought the revision of the Code in 1954 had modified the Palmer principles.

The Gordons and the Baans were mimority shareholders of Pacific. The Gordons sold four of their rights and exercised the remainder. The Baans exercised all of their rights. Neither the Gordons nor the Baans reported any mcome upon the receipt or exercise of the rights, nor did the Gordons report any incoune on the sale. The Commissioner assessed deficiencies based upon the Service's earher private letter ruling. The taxpayers argued, however, that the transaction was a spin-off qualifying for nonrecognition treatment under section 355. A discussion of the use of a rights offering in connection with a section 355 transaction is postponed to Part III of this Article. ${ }^{95}$ For purposes of the present discussion, analysis of the hitigation is useful to determine how the courts viewed the Palmer principles after the enactment of the 1954 Code.

94. Oscar E. Baan, 45 T.C. 71, 85 (1965) (private letter ruling, June 28, 1961).

95. See text accompanying notes 137-53 infra. 
The Tax Court, in an opinion that affirmed the continued vitality of Palmer, ${ }^{96}$ held that the exercise of the rights by the Gordons and the Baans was protected by section $355 .^{97}$ First, the Tax Court noted that if section 355 had not applied, there would be no question that the taxpayers were correctly taxed on the spread between the option price and the fair market value of the Northwest stock on the date of exercise. Moreover, it observed that the Choate problem was not presented since the fair market value of the Northwest stock was not greater on the date of exercise than on the date of the option's issuance. ${ }^{98}$ Second, the Tax Court rejected the Commissioner's contention that the Palmer dictum-that issuance of rights alone is not a distribution of corporate profits-was no longer good law. ${ }^{99}$ In support of this rejection, thecourt noted that the 1954 Code evidenced no congressional intent to overrule any part of the Palmer decision, ${ }^{100}$ and that Palmer had been applied by the Tax Court im cases arising under the 1954 Code. ${ }^{101}$

96. Oscar E. Baan, 45 T.C. $71,87,91$ (1965).

97. Id. at 71. However, the proceeds received by the Gordons from the sale of the rights were held not protected by section 355 and were taxed in full as ordinary income. The Tax Court reaffirmed the earlier analysis of Gibson v. Commissioner, 133 F.2d 308 (2d Cir. 1943), see text accompanying notes 35-37 supra, that the sale of a right was an anticipation of the distribution of a dividend. Therefore, such an anticipation resulted in ordinary income subject to the dividend received credit. Cf. Tobacco Prods. Export Corp., 21 T.C. 625 (1954) (see text accompanying notes 44-46 supra).

98. The court specifically reaffirmed mucl of the Choate opinion:

The Palmer case has generally been regarded as based upon the theory that there may be a taxable dividend where the optioned stock is worth more than the subscription price at the time of offering, and since the Northwest stock lad a value substantially in excess of the subscription price at the time of issuance of the rights, there is not present liere the condition for nontaxability that existed in the Palmer case itself. The scope of Palmer was considered at length in Choate, and, since the value of the Northwest stock on the dates of exercise of the rights herein was not in excess of its value on the date of issuance of the rights the problem which proved so troublesome in Choate is not before us. The Commissioner has charged petitioners with having received dividends only to the extent that the Northwest stock liad a value on the date of exercise of the rights in excess of the subscription price, and sucl excess in turn was less than the corresponding excess as of the time of the offering.

45 T.C. at 87 n.4.

99. Id. at 91 .

100. See text accompanying notes $61-67$ supra.

101. The court cited William H. Bateman, 40 T.C. 408 (1963), for this proposition. But the facts of Bateman are not analogous. In that case two corporations merged and the shareholders of the acquired corporation received common stock of the acquiring corporation and assignable warrants to purchase additional common stock of the acquiring corporation. The merger qualified as an A reorganization, $\S 368(a)(1)(A)$, and the question before the court was wliether the stock warrants were "stock" within the meaning of section $354(a)(1)$ so that they could be received without the recognition of mcoine. The court concluded that the warrants were not "stock" and therefore were taxed as "boot" under section 356.

The Tax Court in Baan noted further that the Commissioner was relying on the employee stock option cases, Smith and LoBue, see text accompanying notes 70-87 supra, as having overruled Palmer. But the Tax Court correctly noted that the Smith and LoBue opinions did not discuss this aspect of Palmer and in other respects cited it with approval. 45 T.C. at 91 n.7. 
The Gordons' case was appealed to the Second Circuit, which affirmed the Tax Court's opinion that section 355 apphed to the transaction. ${ }^{102}$ Nothing in the Second Circuit opinion suggested that Palmer was not fully viable after the enactment of the 1954 Code. ${ }^{103}$ The Baans' case was appealed to the Ninth Circuit, which reversed the Tax Court and held that section 355 did not apply to the transaction. ${ }^{104}$ The Nimth Circuit stated that Pacific's distribution of stock rights constituted a distribution of property within the meaning of sections 317 and 301. Nevertheless, the court restated the Choate analysis of Palmer, that the amount of the dividend was determinable at the tinie of the exercise of the stock rights. ${ }^{105}$ Thus, nothing in the Ninth Circuit opinion suggests that the Palmer dictum that a taxable event occurs only upon date of exercise was not viable after the 1954 Code.

The Supreme Court resolved the conflict between the Second and Ninth Circuits by holding that section 355 did not apply to the transactions. ${ }^{106}$ Consequently, the Baans and the Gordons, having exercised their rights, were required to recognize ordinary income equal to the spread between the option price of sixteen dollars and the fair market value of the Northwest stock at the tinue the rights were exercised. In its opinion, the Court never addressed the contmued validity of Palmer, but it did in dictum suggest that the Palmer-type issues were still open. Specifically, the Court reaffirmed that a sale of corporate property to a shareholder for an amount less than its fair market value has the effect of a "distribution of property" to the shareholders within the meaning of section 316. The Court also stated, however, that although selling property pursuant to a rights offering for less than its fair market value clearly results in a dividend, "[i]t has not . . . been authoritatively settled whether an issue of rights to purchase at less than fair market value itself constitutes a dividend, or the dividend occurs only on the actual purchase." 107 This is a curious statement. Palmer clearly indicated that the issuance of an option itself could never be a

102. Commissioner v. Gordon, 382 F.2d 499 (2d Cir. 1967). However, the Second Circuit reversed the Tax Court's holding that the Gordons realized ordimary income on the sale of the rights, and held instead that the sale yielded capital gams. Id. at 510 .

103. For example, the court stated:

Normally, the distribution of a stock right has no tax consequences because there is no distribution of corporate property until the right is exercised. A sale or exchange of a stock right prior to exercise results in a tax only because it is an anticipation of gain from an exercise.

Id. at 505 (footnote omitted).

104. Commissioner v. Baan, 382 F.2d 485 (9th Cir. 1967).

105. Id. at 494.

106. Commissioner v. Gordon, 391 U.S. 83 (1968). See text accompanying notes $152-53$ infra.

107. 391 U.S. at 89 n.4. 
distribution of property, and the opinion has consistently been so interpreted by the Service and by lower courts. The Gordon statement is inconsistent with Palmer, then, unless the Court meant to suggest that the Palmer limitation apphies only if the option price of the property represents the reasonable value of the property at the tinie the corporation commits itself to sell the property to its shareholders. ${ }^{108}$ If Palmer is so limited, then it remains undecided im the Supreine Court whether, when corporate property clearly is being sold to shareholders at a price less than its fair market value, a dividend occurs on the date of issuance or upon its exercise. In statimg that the question is an open one, the Court did not cite to the 1954 Code or to its employee stock option cases. ${ }^{109}$ Again, the Court unight be willing to distmguish Palmer on its facts and treat the question as undecided both before and after the 1954 Code, thereby avoiding the question whether the 1954 Code overruled Palmer.

Since the Court held that section 355 did not apply to the transaction, one might have expected a resolution of the issue of the timing of the dividend in Gordon. The Court stated, however, that it did not have to answer this as yet undecided question, ${ }^{110}$ presumably because the spread on the date of exercise (the date espoused by the Commissioner) was no greater than the spread on the date of issuance. ${ }^{11}$ Thus, the question was not raised by either the Commissioner or the taxpayer.

Finally, the Supreme Court reversed the Second Circuit on the question of the tax consequences of a rights sale. The Court reasoned, consistent with the earlier Gibson opinion of the Second Circuit, that since the receipt and exercise of the rights would have produced ordinary income, the receipt and sale of the rights-constitutimg merely an alternative route to realization-also produced ordinary income. ${ }^{112}$

All of the lower court opinions concerned with this litigation had held consistently that the Palmer principles had not been affected by the enactment of the 1954 Code. ${ }^{113}$ But the Supreme Court's opinion

108. See id.

109. See text accompanying notes 71-82 supra.

110. 391 U.S. at 89 n.4.

111. On remand to the Tax Court, the Commissioner argued for the first time that the dividend occurred upon the issuance of the right. The court rejected this argument because the deficiency was not based on this theory and the Commissioner never amended his pleadings to ask for any increased deficiency based upon this alternate timing theory. 51 T.C. at 1048.

112. 391 U.S. at 98.

113. Moreover, none of them suggested that the area was unsettled by developments in the taxation of employee stock options when it had clearly been established by the time of this litigation that options with an ascertainable fair market value issued to employees could be taxed to the employee on the date of the issuance of the option. This failure can be easily criticized. 
in Gordon left a hairline crack in this certitude with its statement that the question had never been authoritatively settled whether an option issued to a shareholder was taxable upon its receipt or its exercise.

(b) Revenue Ruling 70-521. Shortly after the Baan and Gordon litigation, the Commissioner took advantage of the Supreme Court's dictum in Gordon that the timing of the dividend distribution (whether it occurred upon issuance or upon exercise of the right) was an open question. In Revenue Ruling 70-521, ${ }^{114}$ the Commissioner stated that the correct timing of the dividend distribution was the date of the distribution of the right. ${ }^{115}$ The Commissioner based his decision upon

114. $1970-2$ C.B. 72 .

115. The revenue ruling sets forth the tax consequences that follow a change in the timing of the dividend from the date of the exercise of the right to the date of its distribution. The following example is based upon the revenue ruling.

Example: Corporation $X$ owned $50 \%$ of the outstanding stock of Corporation $Y . X$ s $\mathrm{s}$ basis in the $Y$ stock was $\$ 10$ per share. $X$ desired to acquire additional capital by selling the $Y$ stock to its shareholders. It therefore distributed pro rata to its shareholders transferable rights to acquire the $Y$ stock for $\$ 15$ per share, exercisable over a four-inonth period. On the date of distribution, the $Y$ stock had a fair market value of $\$ 20$ per share. The rights had a fair market value of $\$ 6$ per right on the date of distribution because of the difference between the option price and the fair unarket value of the $Y$ stock on that date, and because of the length of the option period. The earnings and profits of $X$ were greater than the total fair market value of all rights distributed. The following tax consequences occurred as a result of the rights distribution:

(a) An individual sharcholder of $X$ had a dividend upon the distribution of the right equal to $\$ 6$, the fair market value of the right. $\& 301(\mathrm{~b})(1)(\mathrm{A})$, (c)(1). The shareholder's basis in the right was also $\$ 6 . \& 301(d)(1)$.

(b) A corporate shareholder of $X$ had a dividend of zero upon the distribution of the right because the amount of the distribution to a corporate shareholder was the lesser of $X$ 's adjusted basis im the right (zero) or the fair market value of the right (\$6). \&301(b)(1)(B). A corporate shareholder's adjusted basis in the right was also zero. \& 301(d)(2).

(c) X's earnings and profits were not reduced by the distribution because a corporation's earnings and profits are reduced by its adjusted basis in the property, §312(a)(3), which in this instance was zero.

(d) No gain or loss was recognized by any shareholder who exercised a right. The option price of $\$ 15$ plus the shareholder's basis in the rights exercised became the shareholder's basis in the $Y$ stock. Thus, an individual shareholder had a basis of $\$ 21$ in each share of $Y$ stock, and a corporate shareholder had a basis of $\$ 15$.

(e) Upon the exercise of each right, $X$ recognized a gam of $\$ 5$, the difference between its adjusted basis of $\$ 10$ and the option price of $\$ 15, X$ s earnings and profits were also imcreased by $\$ 5$.

(f) The tax consequences to a shareholder upon the sale of a right were determined under section 1234. Thus, in general, the gain or loss recognized on the sale of the right was a capital gain or loss, provided the $Y$ stock was a capital asset in the hands of the shareholder. § 1234(a)(1). If a right were neither sold nor exercised, the shareholder holding that right had a loss equal to his basis in the right, and that loss was treated as if derived from the sale of the option on the date it expired. \& 1234(a)(2). The loss would normally be capital, and whether it was short-term or longterm would depend upon whether the option period was shorter or longer than one year. See $\S 1223$.

The revenue ruling does not discuss the tax consequences when earnings and profits are less than the total fair market value of all rights distributed. In this circumstance, the taxation of the 
the Court's statement that the issue was open and that the new definition of "property" within section 317(a), which was not contamed in the revenue act under which Palmer was decided, negatively imphed that such rights were "property" by excluding specifically froin the definition rights to acquire stock of the issuing corporation. The problems with this statutory construction argument have been expressed earlier. ${ }^{116}$ Moreover, the Service's position was certainly not inandated by the Court's dictum in Gordon, since the Court did not suggest that the issue was open because of any changes made by the 1954 Code.

(c) Baumer y. United States. The only other reported case that has considered the continued validity of the Palmer principles since the enactment of the 1954 Code is the Fifth Circuit's recent decision, Baumer $v$. United States. ${ }^{17}$ The case concerns an option to purchase real estate rather than portfolio shares. Consequently, the option itself, and perhaps the underlying property, did not have an easily ascertainable nrarket value. This factor of valuation raises issues quite distinct froin those in the portfolio share cases, in which the fair inarket value of the options and the shares is easily determined because they are traded publicly. Nevertheless, this decision is the only opinion since the 1954 Code that has given serious thought to the Palmer issues, and it suggests how these issues should be addressed under the 1954 Code. The facts in Baumer are coinplicated and are described in some detail in order to consider adequately the court's opinion.

In Baumer, $F$ was the sole shareholder of Seven Eighty-Eight Greenwood Avenue Corporation (Corporation), which owned and leased real estate in Atlanta, Georgia. $S$, the son of $F$, was a real estate attorney in Atlanta. In early 1965, $S$ became interested in purchasing Tract $A$, located in Atlanta, and in Noveinber 1965, the owner offered to sell the property to $S$ for $\$ 175,000 . F$ advised $S$ not to purchase the

issuance of stock rights is the same as the taxation of distributions of any other type of property to shareholders. Presumably, current earnings and profits, if any, are allocated pro rata over each $\$ 6$ distribution resulting from the distribution of rights, plus any other distributions of property made during the same taxable year. The current earnings and profits are increased as a result of any gains recognized by $X$ because of the excess of the option price over $X$ 's adjusted basis in the stock. §312(f). The accumulated earnings and profits are next allocated in chronological order. They are allocated first to any distribution occurring prior to the rights offering and then pro rata over each $\$ 6$ distribution resulting from the rights offering, since each such distribution would have occurred at the saine time.

If $X$ s basis in the $Y$ stock had been greater than the option price for the $Y$ stock, would $X$ recognize a loss upon the exercise of a right? As suggested in notes 52 \& 55 supra, $X$ should not recognize a loss in calculating its taxable incoine, although some courts have allowed the recognition of losses in similar situations.

116. See text accompanying notes 64-69 supra.

117. 580 F.2d 863 (5th Cir. 1978). 
property. In early $1966, F$ was advised that an attractive parcel of real estate was available for sale, and he discovcred that it was Tract $A$. Corporation agreed to purchase the property for $\$ 174,000$ in January 1966 . Because $F$ had originally advised $S$ not to purchase the property, $F$ felt some moral obligation to allow $S$ to participate in any future benefits from ownership of the property. In May 1966, Corporation gave $S$ an assignable option to purchase a one-half interest in Tract $A$ at $\$ 88,000$, which was approximately one-half of Corporation's purchase price, exercisable during the next twelve inonths. The stated consideration for the option was ten dollars.

At the time Tract $A$ was purchased by Corporation, it was zoned for residential use, but the area in which it was located was ripe for transition to coinmercial use. Consequently, the rcalization of any value in excess of $\$ 175,000$ depended upon rezoning Tract $A$ to commercial use. $F, S$ and Corporation decided to attempt to develop it as the location of a inotel. The property could not be rezoned for such use without provision for sewer services, but $S$ found an adjacent parcel of land, Tract $B$, that had access to sewer facilities. In August 1966, Corporation purchased Tract $B$ for $\$ 25,000$. At this time Tracts $A$ and $B$, as combined properties, were ehigible for rezoning to commercial use. Accordingly, their value as a unit increased substantially over their value as separate tracts of land.

In January 1967, Corporation granted to $S$ an anended option that covered both tracts $A$ and $B$. The amended option increased the exercise price to $\$ 100,000$, which was approximately one-half of the total purchase price of $\$ 199,000$ paid by Corporation for the two tracts, and extended the option period to June 30, 1969. A few days later, Corporation granted to a real estate brokerage company (Coinpany) an option to purchase both Tracts $A$ and $B$ as a umit for $\$ 500,000$. The option period was six inonths, but Company could extend the period by paying a certain sum per month. The option was assignable and required Coinpany to expend reasonable time and effort to obtam zoning that would permit notel use.

On December 4, 1968, the rezoning application was approved. Two days later $S$ exercised his amended option. The sale to Company was closed on July 1, 1969. Because $S$ exercised his option, Corporation reported a sale of one-half of its interest in Tracts $A$ and $B$ at no gain to $S$, since the option price equalled Corporation's purchase price for the land. Corporation and $S$ each reported a gain froin a sale of their respective one-half interests in the property to Company. $F$ reported nothing with respect to these transactions.

The Government argued that the sale of Tracts $A$ and $B$ should be 
attributable to Corporation. It claimed that the sale was followed by a constructive dividend to $F$, the sole shareholder of Corporation, consisting of the difference between the option price paid by $S$ for a onehalf interest in Tracts $A$ and $B(\$ 100,000)$ and the purchase price paid by Company for one-half the value of these tracts $(\$ 250,000)$. It further contended that $F$ then made a gift of the amount of this constructive dividend to $S$.

The Fifth Circuit held that the sale of the entire property was not attributable to Corporation; rather, one-half of the property was sold by Corporation and one-half was sold by $S .{ }^{118}$ The court also held that the issuance of the option was a distribution of property to be taxed to $F$ as a constructive dividend. The amount of the distribution equalled the value of the option on the date of issuance. Since the value could not be determined on that date, the transaction was left open and the taxation of the dividend distribution was deferred until its value could be determined upon the exercise of the option.

In order to find the existence of a dividend, the court first had to conclude that something of value had been distributed upon the issuance of the option to $S$. The taxpayer argued, citing Palmer, that at the time the option was issued, the exercise price equalled the fair market value of the underlying property and therefore no dividend could have occurred. The court agreed that this proposition appeared to be a correct reading of Palmer, but noted that although the option price equalled approximately one-half the purchase price of Tracts $A$ and $B$ and consequently that there appeared to be no spread on the date of issuance, the combined value of Tracts $A$ and $B$ was greater than the purchase price of each separate tract would suggest. Contrary to the taxpayer's contention, a spread did exist on the date of the issuance of the option, due to this synergism. The court assumed, however, for purposes of the remainder of the opimion, that no spread existed on that date. Thus, Palmer would appear to apply to prevent the occurrence of any dividend. This appearance had to be refuted in the next step of the court's analysis.

The court stated that in valumg an option one must take into account not only any spread between the option price and the fair market value of the property, but also the length of time during which the option could be exercised and the potential appreciation of the underlying

118. See id. This holding was based upon the findings of the lower court that $S$ received his option before a sale of the property to Company was even contemplated, that the option was treated by all persons as a meaningful property interest, that the option was the impetus for $S$ 's personal efforts (which significantly contributed to the appreciation in value of the property), and that $S$ negotiated on his own behalf with Company. 
property during that period. ${ }^{119}$ The option given to $S$ had an exercise period of over two years, during which time it was contemplated that rezoning to commercial use would be obtained, a change that would substantially increase the value of the property. Thus, even if no spread existed on the date the option was issued, a spread would probably develop during the option period, and it was the intent of $F$ to allow $S$ to benefit froin this appreciation. The option was therefore valuable because of its time period and its potential appreciation. The court thought that these two factors distinguished the case from the facts of Palmer. It reasoned that the Supreine Court viewed the issuance of stock rights exercisable within only fifteen days as merely a convenient procedural method by which the sale of property at fair market value could be made by a corporation to a large number of shareholders. The underlying property inight increase in value during the fifteen-day period, but this was always the potential consequence of a sales transaction with a gap between the time of the sales price agreement and the actual sales transaction. The Board of Directors in Palmer, due to the shortness of the option period, could not have intended that the primary purpose of the option was to allow its shareholders to participate in subsequent appreciation in the value of the underlying property.

The Baumer court further buttressed its distinction between short and long option periods by reviewing the Suprene Court's opinion in Smith. In that case, ${ }^{120}$ an einployee received an option to purchase stock of the einployer at a price equal to the fair market value of the stock. The Supreme Court concluded that the employer intended to compensate the employee through a long option period during which the fair market value of the stock was expected to increase in value over the option price. This increase would create a spread that would coinpensate the einployee upon the exercise of the option.

Thus, the Fifth Circuit in Baumer limited the application of Palmer to a situation in which no spread exists on the date of issuance and the option period is so short that it is contemplated that the property subject to the option will be immediately sold to the shareholder before any substantial appreciation in the value of the underlying property can occur. Under the Baumer opimion, the issuance of the option is the distribution of a valuable asset to be taxed as a dividend if a spread exists on the date the option is issued, or if no spread exists on the date of issuance, but the option period is long enough so that the

119. Compare the discussion of valuation of options issued to employees under section 83 , at text accompanying notes 83-87 supra.

120. See text accompanying notes 71-75 supra. 
corporation contemplates appreciation. This analysis looks at the economic effect of the transaction to determine the existence of a dividend, and it correctly encompasses the two factors that attribute value to options-that is, both the existence of a spread on the date of issuance, and the length of the option period and potential appreciation during that period. This viewpoint is consistent with regulations concerning the valuation of employee stock options, which have for many years provided that the valuation of such options must consider both factors. ${ }^{121}$ The incorrect viewpoint of Palmer would have focused only upon the existence of a spread on the date of issuance.

As the final step to its conclusion that the issuance was a taxable event, the Baumer court specifically addressed whether the issuance of the option was a distribution of "property" within the meaning of section 317(a) of the Code. Following the suggestion of several commentators, ${ }^{122}$ the court stated that the specific exclusion of rights to acquire stock in the distributing corporation suggests that rights or options to acquire any other corporate assets constitute the distribution of property within the meaning of section 317(a) for purposes of section 301 . Since the issuance of the option is a section 301 distribution, that section also determmes the amount of the distribution: the fair market value of the property distributed. Because of the lengthy option period, this amount might be different from the spread on the date of the issuance.

Once the court had determined that something of value had been distributed by Corporation to $S$, it easily found a constructive dividend to $F$. The issuance of the option to $S$ primarily served the personal interest of $F$, the sole shareholder of Corporation, to coinpensate $S$ for $F$ s taking advantage of a business opportunity that $F$ had personally discouraged $S$ from pursuing.

The Baumer court had thus far concluded that something of value had been distributed from Corporation pursuant to the issuance of the option to $S$, that this value was taxed to $F$ as a constructive dividend, and that Palmer did not apply to prevent that value from being taxed as a dividend. The court next addressed the question of timing. In dictum, the court noted that prior to the 1954 Code and pursuant to Palmer, the issuance of an option was not a dividend. ${ }^{123}$ However, once the court concluded that section 317(a) of the 1954 Code included a right or option to purchase property in its definition of property, it would see1n necessarily to follow that the time of distribution was the

121. See note 86 supra.

122. See note 59 supra.

123. 580 F.2d at 883 . 
date of issuance rather than the date of exercise.

The court refused to take this logical step. It instead stated that the continued validity of this aspect of Palmer had not been definitively settled by the courts, and that it did not have to decide the issue because it would calculate the same anount of dividend distribution using either date. The amount is the same for the following reasons. Assuming that the dividend distribution occurred when the option was issued to $S$, the value of $S$ 's option was not ascertainable on that date. The taxpayer offered no evidence of the option's value, such as the length of the option period and the likelihood of obtaining a favorable rezoning of the property for commercial use. If the value were unascertainable, the transaction had to remain "open," under the "open transaction" doctrine of Burnet $v$. Logan, ${ }^{124}$ until the option was exercised. Then the amount of the dividend distribution would be determined by the value of the option at the time of exercise. If, however, it was determined that the dividend distribution occurred on the date of exercise, the amount of the dividend would again be the value of the option on the date of exercise. Since the answer would be the saine-the value of the option on the date of exercise-in either event, the court assumed that the date of issuance was the date of the dividend distribution, but that the transaction remained open since the option could not be valued on the date of issuance.

Baumer is the first case that the author has located in which the open transaction doctrine was apphed to a dividend distribution. The doctrine is presently used, as the court noted in Baumer, by statutory requirement in the case of options distributed to employees to purchase corporate property. ${ }^{125}$ The use of the date of issuance and the open transaction doctrine in colmection with a dividend distribution, however, raise some problems.

\section{Problems Associated With the Date of Issuance and the Open Transaction Analysis.}

(a) Measurement of the amount of the dividend. If the taxation of the issuance of an option is postponed until exercise because the option cannot be valued on the date of issuance, then one of two dates-issuance or exercise-must be chosen as the time for ineasuring earnings

124. 283 U.S. 404 (1931).

125. See the discussion of the tax consequences of the issuance to employees of options to purchase corporate property at text accompanying notes 70-89 supra. Under section 83 , the employee is taxed on the value of the option on the date of issuance if the option has an ascertainable fair market value. If the value is not ascertainable on that date, the transaction remains open and the employee is taxed on the spread on the date he exercises the option. 
and profits. When a sales transaction remains open, all payments received with respect to the transaction relate back to the original transaction for purposes of characterizing gain or loss as capital or ordimary. This characterization of sales transactions suggests by analogy that if the distribution occurs on the date of issuance of the option then the earnings and profits associated with that date should be used. ${ }^{126}$ Thus, in determining the extent to which the distribution of an option is taxed as a dividend, the current earnings and profits of the corporation for the year in which the option is issued and the accumulated earnings and profits on the date of issuance are the appropriate measuring rods of the amount of the dividend. That the exact amount of earnings and profits distributed on the date of issuance cannot be ascertamed until a later date should not change the amount of the distribution that is treated as a dividend. On the other hand, if the option period is long, the use of earnings and profits on the date of issuance could in certaim circumstances cause substantial administrative problems. For example, if an option were exercised at the end of an option period that had covered several years, a re-examination of all the distributions made by the corporation between the date of issuance and the date of exercise might be required. Some of these distributions could have been wrongfully treated as dividends, with adjustments prevented by the statute of limitations. These administrative problems suggest that the preferable result may be to treat the transaction as incomplete for tax purposes until the option is exercised, and only then to measure earnings and profits.

Another consequence of the application of the open transaction doctrine may be an imcrease in the amount of dividend imcome recognized by the shareholder. If the underlying property subject to the option is appreciating in value during the option period, the option will, in turn, become inore valuable during the option period. Thus, its value on the date of exercise will be greater than its value on the date of issuance, although not exactly ascertamable at that time. Consequently, the dividend will also be greater than a dividend measured by the value of the option on the date of issuance. Although the open transaction doctrine provides for deferred recognition of income, its offsetting disadvantage $\mathrm{m}$ this instance is an mcrease in the amount of ordinary income that must ultimately be recognized. If the latter disad-

126. For example, if a capital asset held for longer than one year is sold and the transaction must remain open, the first payments received as part of the sales price will be treated as a return of capital represented by the seller's basis in the property. After a full return of basis, the remaining payments are treated as a long-term capital gam because the transaction to which these payments relate was the sale or exchange of a capital asset held for longer than one year. 
vantage outweighs the deferral advantage, the taxpayer will be motivated to attempt to value the option when issued. These factors increase the potential for conflict between the taxpayer and the Service over the appropriate year in which to include the value of the option. ${ }^{127}$

(b) Statute of limitations. The court in Baumer suggested that the Government may be creating statute of limitations problems by arguing that the dividend distribution occurs on the date of the issuance of the option. ${ }^{128}$ If the option has an ascertainable fair market value at that time and is appropriately included in the income of the shareholder on that date, but the option period is fairly long, the Government risks the running of the statute of limitations before it discovers the existence of the issuance of the option. For example, in Baumer, if the option could have been valued on the dates of issuance in 1966 and 1967, the value of the options would have been taxed in those years, but the statute of limitations had already run for those years by the time the Government discovered the existence of the options. On the other hand, it had not run for 1968, the year in which $S$ exercised the option. Would the taxpayer escape taxation altogether in this situation by arguing that the correct years for inclusion of the value of the options were closed, and that he could not be taxed in 1968 on the value of the option on the date of its exercise?

The court in dicta suggested the following solution. If the taxpayer reports the value of the option as a dividend in the year it is issued, but its value is in fact not ascertainable, the dividend is not recognized until the sale or exercise of the option. Otherwise, the shareholder will be taxed twice, once in the year of issuance as reported by the shareholder and again in the year of exercise pursuant to the Service's determination that the year of inclusion is the year of exercise (since the fair market value of the option was unascertaimable in the year it was issued). On the other hand, if the taxpayer fails to report an option as a dividend in the year of issuance and it has an ascertainable value on that date, then the dividend is taxed in the year the option is exercised, although it is taxed at its value on the date of issuance. This approach would protect the Commissioner from discovery of the existence of the option after the statute of limitations has run for the year in which the option was issued. ${ }^{129}$

127. This same problem occurs under section 83 if options are issued to employees. Evidently, Congress did not consider this problem significant enough to prevent the adoption of the open transaction approach under section 83.

128. 580 F.2d at 887 n.35.

129. This type of flexible approach to overcome statute of limitations problems is sometimes called transactional analysis. In the first example, to avoid a double mclusion of income, the 
5. Implications of Baumer. The court in Baumer interpreted Palmer to apply if no spread exists on the date of the issuance and if the option period is so short that no substantial spread is expected to

taxpayer is allowed to remove the value of the option in the year of issnance and receive a refund. This approach allows the correction of an earlier error in the closed taxable year. In order to avoid a double exclusion froin income, the second example suggests that the income, although properly reported in the year of issuance, is reported in the year the option is exercised because the taxpayer is estopped from denying the declaration of his earlier return-that the option was not taxable in the year it is issued. In this example, the earlier mistake is frozen, and is in a sense corrected through the mandate of a second mistake, that is, the taxation of an option with an ascertamable fair market value in the year of its exercise rather than in the year of its issuance.

Some courts, lowever, have refused to make these judicial corrections to assist the taxpayer or the Commissioner. They adopt the sensible approach that as long as the inistake is one of law or innocent oversight, the court will allow the statute of limitations to close the earlier taxable year and the inistake in that year will not be corrected in a later year. For example, in Ross v. Commissioner, 169 F.2d 483 (1st Cir. 1948), the Commissioner assessed a deficiency in the year the taxpayer recevied an actual payinent. The taxpayer claimed that, under the doctrine of constructive receipt, the correct year to report the income was an earlier year for which the statute of limitations had run. Even though the taxpayer had not reported the income correctly in the earlier year, the court held the taxpayer was protected by the statute of limitations and could not be forced to "correct" the earlier mistake by including the income in the later year in which it was actually received. See also Bermet v. Helvering, 137 F.2d 537 (2d Cir. 1943). Still other cases can be cited for the adoption of estoppel principles similar to those suggested by the court in Baumer. They attempt to prevent the taxpayer or the Commissioner from using to his advantage a mistake made in a year in which the statute of limitations has run. See, e.g., Contimental Oil Co. v. Jones, 177 F.2d 508 (10th Cir. 1949); Wichita Coca-Cola Bottling Co. v. United States, 152 F.2d 6 (5th Cir. 1945), cert. denied, 327 U.S. 806 (1946).

The mitigation provisions of sections 1311-1314 assist in solving these admimistrative problems. They provide, in certain specified circumstances, for the correction of an error made in an earlier taxable year even though the statute of limitations has run for that year. Section 1311 provides that if a determination described in section 1312 is made that an item was earlier erroneously included or excluded, and if on the date of determination the correction of the error is prevented by the operation of any law (for example, the statute of limitations), then the effect of the error is nevertheless corrected in the amount and manner specified in section 1314. Section 1312 lists several types of errors. For example, section $1312(1)$ refers to a determination that causes a double inclusion of income by requiring "the inclusion in gross income of an iten which was erroneously included in the gross income of the taxpayer for another taxable year." \& 1312(1). Section $1312(3)$ (B) refers to a determination that causes a double exclusion from income by requiring "the exclusion from gross income of an item not included in a return filed by the taxpayer . . but which is includible in the gross income of the taxpayer for another taxable year." $\S 1312(3)(B)$. The "determinations" that may trigger the correction mclude decisions by the Tax Court, final dispositions of refund claims, and agreements between a taxpayer and the Service "relating to the liability" of the taxpayer for a particular item. § 1313(a).

The following examples illustrate the application of these mitigation provisions in the context of the issuance of options to shareliolders.

Example 1: Taxpayer reports the value of the option as a dividend in 1976, the year the option is issued, but the option does not have an ascertamable value in that year. The taxpayer exercises the option in 1979, and does not include any income in his return as a result of exercising the option. In 1980, the Commissioner assesses a deficiency for 1979 because the value of the option on the date of exercise should have been included in income as a dividend for that year. The Commissioner's position is upheld in the Tax Court. The taxpayer is then permitted to remove the inclusion of the value of the option from his 1976 return in order to prevent the double inclusion of income. § 1311(a); § 1312(1). 
develop in that period. These objective criteria suggest that the corporation does not intend to distribute a dividend to shareholders. Rather, the option technique is merely a procedural device to sell corporate property among a large group of shareholders. This reading of Palmer also avoids the apparent conflict between the Supreme Court's opinion in Palmer and its opinions in Smith and LoBue concerning employee stock options. ${ }^{130}$

The Baumer limitations of Palmer leave two other situations in which the Fifth Circuit will find a corporate intent to distribute a dividend: (1) if no spread exists on the date of issuance but the option period is so long that a spread is expected to develop during the option period, as in Smith and Baumer, or (2), if a spread does exist on the date of issuance, regardless of the length of the option period, as in Choate. Baumer itself is the first situation and specifically holds that such a distribution is taxed as a dividend. In the second situation, the corporation obviously intends a distribution because of the immediate existence of a spread on the date of issuance of the option.

The remaining question in both imstances is whether the distribution occurs on the date of issuance or on the date of exercise. Palmer specifically stated that no distribution of corporate profits could occur because of issuance alone, and Baumer does not read Palmer to state otherwise. The question becomes, therefore, whether the 1954 Code overrides this aspect of Palmer. If a court cannot find a specific override, it will simply have to reject Palmer, presumably on the behef that if the Supreme Court were to consider the issue agam, it likewise would reject this aspect of Palmer. The Fifth Circuit in Baumer, like the Supreme Court in Gordon, found it unnecessary to answer this question

Example 2: A taxpayer is issued an option with an ascertainable fair market value in 1976, but he fails to include it in income for that year. He exercises the option in 1977, but fails to include it as income for 1977. In 1979, the Commissioner assesses a deficiency for 1977, claiming that the value of the option should have been imcluded in the year in which it was exercised. The Commissioner loses this argument in the Tax Court in 1980 after the statute of himitations has run for 1976. The assessment in 1979, although later determined by the Tax Court to be incorrect, in effect tolls the statute of limitations for the correct year of inclusion, 1976, so that even though the statute of limitations technically has run, the Commissioner is entitled to assess a deficiency for 1976. This remedy avoids the double exclusion of an item of income. § 1311(a); \& 1312(3)(B). For this corrective provision to apply, the incorrect assessment for 1977 must have been made by the Commissioner before the statute of limitations expires with respect to taxable year 1976. For example, if the deficiency notice for 1977 were not mailed until Decenber, 1980, the statute of linitations would have run with respect to 1976 and the corrective remedy would not be available. In this instance, the only mitigative remedy available to the Commissioner will be to convince the court to apply an estoppel remedy and, as discussed earlier, not all courts will apply such a remedy.

130. See text accompanying notes 71-82 supra. 
since the arithmetical answer would have been the same whether the answer to the question was affirmative or negative. But the court in Baumer, unlike the lower courts in Gordon, did conclude that the issuance of an option is a distribution of property as defined in section 317(a) of the 1954 Code. It logically follows that if the option can be valued on the date of its issuance, then it should be treated as the receipt of a distribution of property under section 301 and taxed as a dividend to the extent of earnings and profits in the year of issuance. Baumer is the first decision to "all but" hold that this portion of Palmer is no longer viable.

As discussed earlier, ${ }^{131}$ there is no evidence that Congress considered the Palmer decision when it anended the definition of property in the 1954 Code. Nevertheless, that definition is certainly broad enough to allow a court interested in ending the apphication of the Palmer dictuin to hold that the issuance of an option itself is a distribution of property withm the meaning of section 317(a). This result would ease the administrative problems of determining the tax liability of shareholders who receive identical, narketable options, but the change would create several administrative probleins when the open transaction doctrine must be applied to options without a determinable value. ${ }^{132}$ It nonetheless appeals to one's sense of intellectual order by bringing the taxation of options distributed to shareholders im line with the statutory taxation of options issued to einployees as compensation. ${ }^{133}$

Notwithstanding the appeal of these arguments, one inust retain some sense of reservation about judicial intervention at this time. Consider the opinion that would necessarily accompany a change in taxation of options to the date of issuance. The court would probably want to limit Palmer to its facts - the existence of no spread on the date of the Board's decision to issue the option, plus a very short option period. This step might be unnecessary if the court were willing to find that the 1954 changes specifically overruled the Palmer primciples, but that willingness should come haltimgly because of the congressional silence. A narrow reading of the holding in Palmer - that the issuance of an option for a short time to purchase property for its fair market value is not a dividend-would lessen the conflict of Palmer with the next step in the hypothetical court opimon. The language of the 1954 Code is so broad that it indicates the purpose to tax the value of all transfers of property to shareholders at the time of receipt, and since options are

131. See text accompanying notes 61-69 supra.

132. See text accompanying note 124 supra.

133. See text accompanying notes 70-87 supra. 
clearly "property" they fall easily within the scope of the statutory scheme for the taxation of dividends. The court could also buttress the soundness of its results by referring to economic good sense (the option obviously is a valuable property right) and administrative ease (it makes unnecessary the many subsidiary rules that developed after Palmer in, for example, Choate, Gibson, and McGuire). All of these considerations would support a court's effort to repudiate the continued application of Palmer without expressly overruling it. But consider the resulting opimion further. It would limit Palmer to its facts; ignore the express dictum in Palmer that the issuance of an option is never a distribution of corporate profits; read into the 1954 Code an overriding of the dictum in Palmer, when the legislative history indicates that Congress did not have Palmer specifically in mind; and, finally, buttress its result by looking at the administrative needs of the Service, a task better suited to Congress.

Finally, if a court decided to hold Palmer invahid, it would begin afresh with a new rule-that options are to be taxed when they are distributed. To be sure, as illustratcd by Revenue Ruling 70-521,134 this change in the law would greatly simplify the determination of the tax consequences when marketable options are issued; but it would also create the potential for a new generation of opimions, not unlike Choate, Gibson, and McGuire, addressing the problems associated with the issuance of options that are not transferable, or are subject to conditions, or do not have a readily ascertainable fair narket value on the date of issuance. As suggested in Baumer, the valuation problein brings into play the open transaction doctrine, and this in turu raises issues pertaining to the calculation of earnings and profits and the application of the statute of limitations. Although these types of administrative probleins have been assuned in the area of employee stock options, they liave been assuined pursuant to the enactment by Congress of section 83 and the issuance of detailed regulations under that section. Of course, the task of answering the questions pertaming to the taxation of options issued to shareholders may be simplified by utilizing the solutions offercd by section 83 and the accompanying regulations.

The question of the continuing validity of Palmer after the enactment of the 1954 Code is not easily answered. Even if a court were willing to overrule Palmer, however, in order to "clean up" the coinplexity of the taxation of options, it would also introduce a new set of issucs requiring subsequent determination on a piecemeal basis. The

134. $1970-2$ C.B. 72. 
prospect of continuing litigation suggests that a prudent court, faced with a request by the Commissioner to overrule Palmer and to accept the Service's position in Revenue Ruling 70-521, may refuse that request and thereby leave the issue to Congress. A legislative response overruling Palmer could deal simultaneously with the questions created by that change. The appendix to this Article presents a suggested statutory solution.

\section{IsSUANCE TO SHAREHOLDERS OF STOCK RIGHTS IN CONNECTION WITH SeCtion 355 Transactions}

Congress allows the division of a corporation without recognition of gain or loss to the shareholders if the requirements of section 355 of the Code are inet. In particular, a parent corporation that controls a subsidiary corporation may distribute to its shareholders stock representing a controlling interest in the subsidiary without the recognition of gain or loss to the shareholders. Absent section 355, this distribution would be treated as a distribution of property to which section 301 applies. Soune corporations desire to use these distributions to raise additional capital for the parent. The parent corporation may adopt a rights offering pursuant to which it issues rights pro rata to its shareholders to purchase stock of the subsidiary at a bargain price. The rights are then exercised and the stock of the subsidiary is distributed.

The government contends that if a rights offering is used in connection with the distribution of the subsidiary's stock, the distribution does not qualify for nonrecognition treatinent under section $355 .{ }^{135}$

135. The requirements of section 355 are discussed in this Article only to the extent necessary to address adequately the issue of the application of that section when a rights offering is used to distribute the stock of the subsidiary. Nevertheless, all of the requirements of section 355 are briefly summarized here.

1. Property distributed. The property distributed to the slareholders of the parent corporation must consist solely of stock or securities of a corporation that the distributing corporation controls immediately before the distribution. $\S 355(\mathrm{a})(\mathrm{I})(\mathrm{A})$. "Control" for purposes of section 355 is defined in section 368 (c) as the ownership of stock that carries at least $80 \%$ of the total combined voting power of all classes of stock entitled to vote, and at least $80 \%$ of the total number of shares of all other classes of stock of the corporation.

2. Device for distribution of earnings and profits. The transaction must not have been uscd principally as a device for the distribution of the earnings and profits of the distributing corporation or the controlled corporation or both. $\S 355$ (a)(1)(B).

3. Active business. Immediately after the distribution, there must be two or more corporations, each engaged in the active conduct of a trade or business. Each of these businesses must have been active for at least a five-year period ending on the date of the distribution. $\S 355(\mathrm{a})(\mathrm{l})(\mathrm{C})$, and (b).

4. Distribution of all stock and securities in the controlled corporation. The distributing corporation inust either (a) distribute all of the stock and securities of the controlled corporation it held immediately before the distribution, or (b) distribute an anount of stock in the controlled corporation constituting "control" withm the meaning of section $368(c)$ and establish that its re- 
The government has made several arguments in support of its position agamst the application of section 355 :

1. The distributing corporation does not distribute "solely stock or securities" within the ineaning of section 355(a)(1)(A) because it issues rights instead, and rights to purchase stock are neither "stock" nor "securities" within the meaning of that section.

2. The distribution of rights is not a distribution of the stock of the subsidiary "to a shareholder with respect to its stock" (that is, to a shareholder of the parent corporation with respect to the parent stock) within the ineaning of section 355(a)(1)(A). Rather, what are distributed with respect to the stock are the rights followed by a cash sale (not a distribution) of the subsidiary stock to holders of transferable rights.

3. The distribution, in certain circumstances, does not meet the requirements of section $355(\mathrm{a})(1)(\mathrm{D})$ that stock constituting control be distributed to the shareholders; that is, the rights offering must yield a purchase by shareholders of eighty percent or more of the subsidiary stock.

4. If many shareholders sell rather than exercise their rights, much of the subsidiary stock will be distributed to purchasers who are not shareholders of the parent. Consequently, the continuity-of-shareholder-interest test is not met. The net effect of the transaction is that too many of the shareholders of the parent end up with cash rather than with a continuing proprietary interest in the stock of the subsidiary.

These arguments are discussed below in the context of the two cases that have considered the use of stock rights in a section 355 transaction.

\section{A. Commissioner v. Gordon. ${ }^{136}$}

The facts of Gordon were described at length in Part II of this

tention of any stock or securities in the controlled corporation is not made in pursuance of a taxavoidance plan. $\S 355(\mathrm{a})(\mathrm{l})(\mathrm{D})$.

5. Business purpose. The distribution of stock and securities in the controlled corporation must be made for some busmess purpose. This is an extra-statutory requirement established by Gregory v. Helvering, 293 U.S. 465 (1935).

6. Continuity of interest. Section 355 contemplates the continuity of the busimess enterprise and the continuity of the proprietary interests of the persons who were shareholders of the distributing corporation prior to the division. The proprietary interest must be contimued in the form of stock ownership in either the distributing or the controlled corporation, or both.

For a detailed discussion of these requirements, see B. BITTKER \& J. Eustice, Federal InCOME TAXation of Corporations and SHaReHolders ch. 13 (3d ed. 1971 and Supp. 1978); D. Kahn \& P. Gann, Corporate Taxation and Taxation of Partnerships and Partners ch. 9 (1979).

136. The seven decisions comprising the Gordon hitigation are cited at note 93 supra. 
Article. ${ }^{137}$ To review, Pacific desired to distribute enough stock of its subsidiary, Northwest, to give Pacific's parent, A.T.\&T., over fifty percent control of Northwest, and simultaneously to charge the Pacific shareholders for the Northwest stock in order to raise additional capital for Pacific. Pursuant to these two business purposes, Pacific issued pro rata rights to its shareholders, offering approximately fifty-seven percent of the Northwest stock for the exercise of six rights plus the payment of sixteen dollars. The sixteen dollar payment was less than the fair market value of the Northwest stock. The remaining forty-three percent of the Northwest stock was similarly distributed about two years later. As discussed earlier, the courts agreed that unless some nonrecognition section applied, the distribution of the Northwest stock upon exercise of the rights would be taxable as a dividend. The Baans and the Gordons, minority shareholders of Pacific, argued that section 355 applied to the transaction and, therefore, that they were not taxed on either exercise or sale of their rights.

The Tax Court held that section 355 applied to the transaction. It countered the Commissioner's first and second arguments by reiterating the Palmer language that issuance of a stock right is not considered the distribution of corporate property; rather, the distribution occurs only upon the exercise of the right. Thus, for purposes of section 355, no corporate property-stock, securities, or otherwise-is distributed at the moment of issuance. Corporate property is distributed only when the rights are exercised, and upon exercise, stock of a subsidiary is distributed to shareholders of the parent corporation as required by section 355(a)(1)(A). Because the court concluded that stock rather than rights were distributed within the meaning of section $355(\mathrm{a})(1)(\mathrm{A})$, it was unnecessary to resolve the issue of whether the rights themselves are "stock or securities" within the meaning of section $355(\mathrm{a})(\mathrm{l})(\mathrm{A}) .^{138}$

The Commissioner argued unsuccessfully that Palmer was no longer valid with respeet to the issuance of rights as a nondistribution of corporate property. The Tax Court specifically rejected the contention that in the 1954 Code Congress imtended to disapprove any part of the decision. ${ }^{139}$ Nor did the court believe that payment by the parent conipany's shareholders for stock of the subsidiary caused the distribu-

137. See text accompanying notes 93-113 supra.

138. According to the regulations, stock rights or stock warrants are not included in the term "stock or securites" as used in either section 355 or section 354. Treas. Reg. $\$ \$ 1.355-1$ (a) (1955), 1.354-1(e) (1955). Accord, William H. Bateman, 40 T.C. 408 (1968) (warrants did not constitute stock within the meaning of section 354). For a general discussion of whether rights or warrants should be included in the term "stock or securities," see BITTKER \& EUSTICE, supra note 135, q 14.31 at $14-75$ to -77 .

139. 45 T.C. at 91 n.7. 
tion to fall outside the protection of section 355. In particular, the transfer of Northwest stock accompanied by consideration did not prevent the transaction from being a "distribution with respect to stock" within the neaning of section 355(a)(1)(A).

At this stage of the litigation, the Commissioner did not make his third argument, that stock constituting control must be distributed to the shareholder. ${ }^{140}$ With respect to the Commissioner's fourth argument regarding the sale of rights and the continuity-of-shareholder-interest, ${ }^{141}$ the court found no substantial question of comphance with section 355 since the purchasers of the stock rights could be viewed as having received the stock "through" the shareholders of the parent corporation. Moreover, in this instance, more than eighty percent of the shares were in fact distributed to shareholders of Pacific. ${ }^{142}$

On appeal, the two circuits spht on the section 355 issue. The Ninth Circuit accepted all of the Government's arguments and the Second Circuit rejected all of the Government's arguments. ${ }^{143}$ In the Second Circuit appeal, ${ }^{144}$ the Government added the argument that because only fifty-seven percent of the Northwest stock was distributed in the first offering, Pacific did not distribute control in a single transaction as required implicitly by section 355 (a)(1)(D). The court agreed with the taxpayer, however, that it was not necessary to distribute the stock in a sinigle offering if control were distributed pursuant to a single plan. Finally, the court notcd that contnuity-of-shareholder-interest was inanitained because over ninety-five percent of the Pacific sharelolders exercised their rights and became shareholders in Northwest. ${ }^{145}$

Judge Friendly, in dissent, agreed with the Government that the

\footnotetext{
140. See text accompanying note 135 supra.

141. 45 T.C. at 91 n.7.

142. Id. at 94 n.9.

143. See text accoinpanying notes 102-05 supra.
}

144. 382 F.2d 499 (2d Cir. 1967). The Second Circuit's opinion closely tracks the reasoning used by the Tax Court. That is, the circuit court agreed that under Palmer the actual distribution in a rights offering is the distribution of the stock upon exercise of the right. The circuit court viewed the transaction as a corporate division connbined with the making of additional capital contributions to Pacific. A contribution of capital to a corporation is not a taxable event to the corporation. \$118. In this instance, however, Pacific recognized a gain to the extent that the $\$ 16$ payment exceeded Pacific's adjusted basis in the Northwest stock. Thus, the Second Circuit's division of the transaction into a section 355 transaction, plus the payment of additional capital to the corporation, is erroneous.

145. In fact, A.T. \& T. alone owned over $80 \%$ of the stock of Pacific and, in turn, received over $80 \%$ of the Northwest stock distributed pursuant to the rights offering. This percentage would be sufficient to meet the contimuity-of-shareholder-interest requirement. As developed by the cases and as administratively applied by the Service, this requirement is met if shareholders owning at least 50\% of the outstanding stock of the transferor corporation (in this case Pacific) retain their equity ownership interest when they go through a corporate division or reorganization, although the form of that equity interest may change as a result of the corporate division or reorganization. 
transaction failed the section 355(a)(1)(D) test for passage of control: the tax consequences of the first offering in 1961 could not be held to depend upon the second offering in 1963, since in 1961 the time and amount of any future offerings were subject to the total discretion of Pacific's Board of Directors. In other respects Judge Friendly found the Government's position more consistent with the language of the statute. For example, he thought, without deciding, that a distribution of rights did not ineet the requirement in section 355(a)(1)(A) that stock or securities be distributed. It appeared to him, in accordance with the Government's arguinent, that what were distributed were rights, and that the stock was distributed with respect to those rights.

Judge Friendly's approach to the interpretation of section 355 was very different from that of the majority of the Second Circuit panel and that of the Tax Court. Both the Tax Court and the Second Circuit believed that the existence of a business purpose for distributing the stock through a rights offering, and the lack of evidence of a device to distribute earnings and profits of Pacific through the distribution of the Northwest stock, precluded the transaction from possessing the potential evils that section 355 was designed to prevent, particularly the conversion of ordmary income to capital gains. ${ }^{146}$ Both courts termed the

For a general discussion of the continuity-of-shareholder-interest requirement, see BITTKER \& Eustice, supra note 135, ๆ 14.11 .

146. If nonrecognition were granted for corporate divisions without restriction, a corporation could utilize them to distribute unneeded assets to a shareholder without the distribution being taxed as a dividend. To take an extreme example, a corporation with $\$ 100,000$ in excess working capital could transfer those unneeded assets to a new subsidiary and distribute the stock of the subsidiary pro rata to its shareholders. The shareholders could then hquidate the corporation in order to obtain the assets. The transaction could be treated as a nontaxable corporate division followed by a hiquidation distribution taxed at the capital gains rate of the shareholder. Notwithstanding this tax-avoidance potential for devisive transactions, as early as 1918 certain types of corporate divisions were nontaxable transactions. The Revenue Act of 1924, Pub. L. No. 68-176, $\S 203(\mathrm{e}), 43$ Stat. 253,257 , permitted a spin-off without tax consequences (that is, the parent corporation distributes stock representing a controlling interest in its subsidiary to one or more of the parent's shareholders and requires no surrender of parent stock). These blanket tax exemptions were accoinplished without qualification despite the ease with which they could be used to avoid dividend treatment for distributions of property. The Supreme Court foreclosed this tax-avoidance potential in Gregory v. Helvering, 293 U.S. 465 (1935), by holding that a spin-off transaction that complied completely with the statute nevertheless would be taxed as a dividend distribution when the substance of the transaction was indistinguishable from a nornal dividend distribution. Because of the tax-avoidance potential highlighted by Gregory, Congress in 1934 eliminated nonrecognition treatinent for all spin-offs. The Code was amended in 1951 to provide for tax-free spin-offs if certain conditions were met, but this provision was quickly superseded in 1954 by the enactment of section 355 , which provides specific conditions equally applicable to all types of corporate divisions.

The central problem of divisive transactions is to distinguish those transactious that divide the corporation but retain the shareholders' investments within one or more corporate entities, from those transactions that represent distributions of corporate earnings and profits taxed as distributions under section 301. Rather than totally disallow sucl transactions, as Congress disal- 
Government's arguments "technical." Judge Friendly reasoned, in contrast, that notwithstanding the existence of a business purpose and the lack of a tax avoidance motive, Congress had not chosen to make all such distributions tax-free; rather, Congress had set extreinely detailed conditions for nonrecognition. ${ }^{147}$ Judge Friendly's view of section 355 is consistent with the historical background of the section, which illustrated that at one time Congress considcred the potential for tax avoidance so great that it did not allow any such distributions to be tax-free even if they were accomplished for a valid busmess purpose. ${ }^{148}$ Given this background and the natural reading of the statute, Judge Friendly refused to accept a taxpayer argument that did not rest easily beside the language of the statute, even though a decision in the taxpayer's favor would not have promoted any tax avoidance schemes or so-called "loopholes" in the statute.

Untike the Second Circuit and the Tax Court, the Ninth Circuit accepted all of the Government's arguments and held that section 355 did not apply. ${ }^{149}$ First, it concluded that stock rights, and not stock, were distributed to the Baans with respect to their stock in Pacific, and that such rights were not "stock or securities" within the meaning of section $355(a)(1)(A)$. Even assuming that the issuance of the rights would not prevent the subsequent distribution of stock froin complying with that subsection, the court held that section 355 did not apply to a distribution in which the shareholders contributed some consideration. It considered the words "distribution with respect to stock" "a term of art . . . used only to refer to distributions without consideration, not to sales for a cash consideration." 150 The court also noted the interrelationship of consideration and continuity-of-shareholder-interest: because transferable rights were issued to purchase stock at a bargain price payable in cash, a substantial number of the parent corporation's

lowed spin-offs in 1934, section 355 permits them but places substantial restrictions upon qualifying them as nontaxable events. These restrictions are imposed primarily to increase the likelihood that the transaction is a mere change of the form $\mathrm{m}$ which the corporate business (or businesses) is conducted, rather than a device to distribute corporate earnings and profits. See note 135 supra for a discussion of these restrictions.

147. 382 F.2d at 512 .

148. See the discussion of the history of the taxation of corporate divisions in note 146 supra.

149. 382 F.2d 485 (9th Cir. 1967).

150. Id. at 493 (footnote omitted).

Although the court cited no authority for its interpretation of the words "distribution with respect to stock," it suggested, by reference to other provisions of Subchapter C, that this interpretation would cause no problems in other provisions in which that same language is used. The court referred to the bargain sale regulations under section 301 as support for its interpretation and commented that the regulations do not suggest that such a transaction is in fact a distribution. Rather, the regulations state that such a transaction will be treated as a distribution for purposes of section 301. 
shareholders might sell the rights for cash and not become direct shareholders of the subsidiary corporation. The court felt that to place a rights offering within the provisions of section $355(\mathrm{a})(1)(\mathrm{A})$ was inconsistent with the continuity-of-shareholder-interest requirement and would cause probleins of interpretation im subsequent cases involving substantial sales of rights.

Finally, the Ninth Circuit agreed with the dissenting opinion of Judge Friendly in the Second Circuit that the distribution did not meet the requirements of section 355(a)(1)(D). The court stated that multiple distributions should be allowed under section 355 only if "reasonably necessary" to alleviate the practical problems of single distributions. ${ }^{151}$ On appeal, the Supreme Court agreed: ${ }^{152}$ if the two distributions are to be tied together, the second step inust at least be identifiable at the tine of the first step. It would be inconsistent with the Code and its concepts of annual accounting to allow the tax consequences of a distribution in 1961 to depend upon another, indeterminate future distribution.

The Supreme Court also agreed with Judge Friendly that section 355 must be construed in accordance with its natural meaning, notwithstanding that this interpretation would prevent the tax-free accoinphishment of a transaction that appeared to fit the general purpose of the statute.

It is no doubt true, as the Second Circuit emphasized, that the general purpose of the section was to distinguish corporate fission from the distribution of earnings and profits. However, although a court may have reference to this purpose when there is a genuine question as to the meaning of one of the requirements Congress has imposed, a court is not free to disregard requirements simply because it considers them redundant or unsuited to achieving the general purpose in a particular case. Congress has abundant power to provide that a corporation wishing to spin off a subsidiary must, however bona fide its intentions, conform the details of a distribution to a particular set of rules. ${ }^{153}$

After this extended litigation, only one of the Government's arguments, the interpretation of section 355(a)(1)(D), was definitively decided by the Supreme Court. The Second and Ninth Circuits split on the other three arguments. Nevertheless, the Supreme Court's guideline concerning the interpretation of section 355 should be helpful in determining whether the Second or the Ninth Circuit was correct with respect to the other Government arguments.

151. 382 F.2d at 498 .

152. Commissioner v. Gordon, 391 U.S. 83, 96 (1968).

153. Id. at $92-94$. 


\section{B. Redding v. Commissioner.}

The only other case to consider the use of a rights offering in connection with a section 355 distribution was Redding v. Commissioner, ${ }^{154}$ recently decided by the Tax Court and presently on appeal to the Seventh Circuit. As might have been expected, the Tax Court's analysis in this case followed to a great extent its reasoning in the Gordon and Baan cases. It again held that section 355 protected the shareholder froun recognition of incolne on the distribution of the subsidiary's stock when the rights were exercised. The opinion is iniportant, first because it comes after the Supreme Court's admonition to the Second Circuit in Gordon not to ignore the express requirements of the statute and, second, because it comes after substantial discussion that the Palmer principles are no longer valid. It is therefore interesting to see how the Tax Court handled these two problems. First, however, the facts of the case must be described.

Indianapolis Water Coinpany (Water), a public utility, owned all the outstanding stock of Shorewood Corporation (Shorewood), which was in the busmess of operatimg, developing, and selling real estate. In 1970 , Sliorewood reduced the par value of its stock from $\$ 100$ to $\$ 1$ per share and increased the number of authorized shares from 1,000 to $2,500,000$. On the same day, Shorewood issued to Water 481,291 shares of its $\$ 1$ par value common stock in exchange for Shorewood's 1,000 shares then outstanding and held by Water. On January 6, 1971, Water agreed to purchase 855,360 additional shares of Shorewood common stock. On January 7, 1971, Water distributed to its shareholders riglits, evidenced by transferable warrants, to acquire an aggregate of $1,069,537$ of the Shorewood shares. These shares comprised the 855,360 shares to be acquired by Water plus 214,177 of the 481,291 sliares that Water already lield. Each right consisted of a primary right to subscribe for one share of Shorewood upon the surrender of two rights and the payment of $\$ 5$, and an additional privilege to subscribe at the same price ( $\$ 5$ per share) for all shares not taken pursuant to the exercise of the primary riglits. The subscription privilege was subject to the right of the underwriter to purchase up to 50,000 shares of Shorewood. The subscription offer expired on January 23, 1971.

During the subscription period, the rights were traded over the counter. The shareliolders of Water or the purchasers of their warrants subscribed to all of the shares offered except the 50,000 shares acquired by the underwriters. After the Shorewood shares were distributed, Water continued to own 267,114 shares of Slorewood. Pursuant to the 
rights offering, Water distributed 1,069,537 shares of Shorewood, but 50,000 of these shares were acquired by the underwriters. The $1,069,537$ shares constituted one share more than eighty percent of the total number of shares of Shorewood stock outstanding. Taking into account the shares issued to the underwriters, the shares that Water retained, and the shares issued to purchasers of the rights, the Water shareholders owned inore than fifty percent but less than eighty percent of the outstanding Shorewood stock.

Mr. Redding was a shareholder of Water and received rights to purchase Shorewood stock. He exercised the primary subscription rights, but he reported no income from either the receipt or the exercise of the rights. The Commissioner argued in accordance with Revenue Ruling 70-521 ${ }^{155}$ that the distribution of the rights was a dividend equal to the fair market value of the rights on the date of distribution. The taxpayer argued, however, that the rights offering was a procedural step to effectuate a corporate separation that qualified for nonrecognition treatment under section 355, or if section 355 did not apply, that under Palmer he realized incoine only upon the exercise of the rights. In accordance with Choate, the amount of income would then be the lesser of the spread between the option price and the fair market value of the stock on the date the rights were issued, or on the date the rights were exercised. In response, the Commissioner argued that the transaction did not coinply with section 355 because it did not comply hterally with the language of subsection (a)(1)(A); Congress never intended the use of stock rights in connection with a section 355 transaction; and the rights offering had independent significance from the distribution of the Shorewood stock, simce there was no guarantee when the rights were distributed that enough stock wonld be subscribed for to yield a distribution of at least eighty percent of the Shorewood stock as required in subsection (a)(1)(D).

The court, in rejecting the Commissioner's arguments and in holding that the transaction was covered by section 355 , largely tracked its earlier reasoning in Oscar E. Baan. ${ }^{156}$ It held that the rights offering was inerely procedural and the net effect was a corporate division within the meaning of section $355 .{ }^{157}$ The court relied, as it had in Baan, upon the Palmer dictum that no distribution of corporate property occurred until the option was exercised. This determination is unconvincing for two reasons. First, treating rights in a section 355 transaction as merely procedural suffers from the same failing as did

155. 1970-2 C.B. 72. See text accompanying notes 114-16 supra.

156. 45 T.C. 71 (1965). See text accompanying notes 96-101 supra.

157. 71 T.C. at 612-13. 
the Palmer dictum - the rights themselves are valuable items of property freely traded on the market. They represent a distribution of property to the shareholders because they give something not possessed before-the right to demand direct ownership of certain corporate property and the power to sell that right to nonshareholders. It is thus economically unreahistic to view the distribution of rights as merely a procedural device. Second, the Palmer dictum has arguably been overruled by section 317(a) of the 1954 Code. ${ }^{158}$ Thus, if the distribution of a taxable right is a distribution of property, as defined under section 317(a), taxed to the shareholder under section 301 upon its distribution, the court's treatment of the distribution of rights as "merely procedural" is conceptually inconsistent with sections 301 and 317 . This inconsistency indicates that the rights distribution should be treated as protected by section 355 only if the statute clearly states that the distribution of rights is within the statute. As argued by the Commissioner, the statute states otherwise-that section 355 applies only when stock or securities of the parent corporation are distributed to a shareholder with respect to its stock. ${ }^{159}$ Thus, the court's holding-that the issuance of the rights under section 355 is inerely procedural-is sound only if the Palmer dictum is still valid, a question not addressed by the court. It is not a sufficient justification for the Tax Court to ignore this unresolved issue and to allow the rights offerings to qualify under section 355 because none of the evident congressional concerns are violated, when it is not apparent that Congress had such rights offerings in mind when it enacted section 355 , and the express language of the statute does not yield easily to such an interpretation.

Even assuming that the court's "merely procedural" determination is correct, that conclusion raises several other problems not adequately dealt with by the court. First, if the issuance of the rights is procedural, then what is distributed within the ineaning of section 355 is the Shorewood stock. Many of the Water shareholders sold their rights, so that the Sliorewood stock was distributed to a substantial number of persons not shareliolders of Water. This fact raises two problems of interpretation under section 355. First, subsection (a)(1)(A) states that stock or securities of the subsidiary corporation must be distributed to the shareholders of the parent corporation with respect to its stock. Once the rights are issued, shareholder status becomes irrelevant, and this result seems inconsistent with the language of subsection (a)(1)(A) and the general intent of section 355 that the corporation be divided among the present shareholders of the parent corporation. The court re-

158. See text accompanying notes 61-69 supra.

159. See note 138 supra. 
sponded to this argument by noting that the status of the Water shareholders was important because their existence created any purchaser's right to receive the stock. ${ }^{160}$ But this analysis is strained in comparison to the straightforward interpretation of the statute, suggested by the Commissioner, that section 355 conteinplates distributions to shareholders. The court nevertheless thought the problem inconsequential in this case because the shareholders of Water actually received more than fifty percent of the Shorewood stock, sufficient percentage to satisfy the continuity-of-shareholder-interest test. Thus, the court superimposed a judicial gloss upon subsection (a)(1)(A): it was sufficient that at least fifty percent of the stock or securities of the subsidiary end up in the hands of shareholders of the parent when section 355 applied to a rights offering. ${ }^{161}$

160. One may see them as receiving the stock "through" the shareholders of Water, as suggested by the Tax Court in Gordon. See text accompanying notes 141-42 supra.

161. See note 145 supra for a brief discussion of the $50 \%$ requirement. The apphication of the continuity-of-shareholder-imterest requirement to a rights offering is somewhat different from the normal factual situation under section 355 or the reorganization provisions, which raise a question of compliance with that requirement. Compare the following two examples.

Example 1. Corporation $X$ is owned equally by four shareholders, $A, B, C$, and $D$. $X$ owns all the outstanding stock of Corporation $Y$. $X$ distributes half of the $Y$ shares to $A$ and the other lialf to $B$. $C$ and $D$ each receive cash distributions equal to the fair market value of the $Y$ stock distributed to $A$ and $B$. Thus, each shareholder receives a pro rata distribution, but $A$ and $B$ receive $Y$ stock and $C$ and $D$ receive cash. $C$ and $D$, who received cash, have essentially sold their interests in the $Y$ stock for that cash, while $A$ and $B$ have essentially purchased the interests of $C$ and $D$ in the $Y$ stock for cash. But after these transactions, all of the $Y$ stock ends up in the liands of shareholders of $X$.

Example 2. Corporation $X$ is owned equally by four shareholders, $A, B, C$, and $D . X$ owns all the outstanding stock of corporation $Y$. $X$ distributes to its shareholders transferable rights to purcliase the $Y$ stock. $C$ and $D$ sell their rights to $E$ and $F$. Thereafter, $A, B, E$, and $F$ exercise the rights and receive pro rata the $Y$ stock. After these transactions, only $50 \%$ of the $Y$ stock ends up in the hands of the $X$ shareholders, since other $X$ shareholders sold their interests in the $Y$ stock for cash to nonshareholders of $X$.

For purposes of applying the continuity-of-shareholder-interest requirement, should these two examples yield different results? The net effect in both examples is that $C$ and $D$ have sold their interests in $Y$ for cash; only the purchasers of their interests are different. In both transactions, however, $A$ and $B$ retaim their interests in $Y$. Therefore, the continuity-of-shareholderinterest test arguably is met in both examples, because the important result is that shareholders owning at least $50 \%$ of the stock of $X$ retain their interests in $Y$. Nevcrtheless, this interpretation of the continuity-of-shareliolder-interest requirement in the context of section $\mathbf{3 5 5}$ nay be incorrect. As discussed in detail in note 162 infra, if one looks at all the requirements of section 355, and especially the device restriction in section 355(a)(1)(B), the intent of Congress in forming those requirements seems to be that all of the stock of the subsidiary inust coine to rest in the liands of the shareholders of the parent. Under the device restriction, for example, pre-arranged sales of substantial amounts of the subsidiary's stock disqualify the transaction for nonrecognition under section 355. Moreover, section 355 expressly contemplates a corporate division in which some of the shareholders of the parent do not receive stock of the subsidiary. In that case, however, all of the stock of the subsidiary is still distributed only to shareholders of the parent. Section $355(\mathrm{a})(2)(\mathrm{A})$ provides that section 355 shall be apphied without regard to whether the 
The receipt of a substantial amount of the Shorewood stock by persons who were not shareholders of Water also raised a question of statutory interpretation under subsection (a)(1)(D), which requires that at least eighty percent of the stock of the subsidiary be distributed. Water distributed through the rights offering exactly one share over eighty percent of the total outstanding stock of Shorewood, but less than eighty percent was distributed to the shareholders of Water, because several sold their rights and 50,000 of the shares were distributed to the underwriter. The majority of the Tax Court determined that the eighty percent requirement had been met, but Judge Sterrett, im dissent, stated that subsections (a)(1)(A) and (a)(1)(D) should be read in conjunction to require the distribution of eighty percent of the stock (under subsection (a)(1)(D)) to the shareholders of the parent corporation (under subsection (a)(1)(A)). It is hard to disagree with Judge Sterrett; the statute seems to contemplate the distribution of at least eighty percent of the subsidiary corporation's stock only to shareholders of the parent corporation. The imtent of the statute is to contimue the businesses of the parent and the subsidiary corporation in the hands of those shareholders. ${ }^{162}$ The statute does not provide for corporate divi-

distribution of the stock of the subsidiary is pro rata with respect to all of the shareholders of the parent corporation.

162. This intent is evidenced by both the continuity-of-shareholder-interest requirement and the device restriction. In order to be tax-free under section 355, a distribution inust not be used "principally as a device for the distribution of earnings and profits" of the parent corporation, or the subsidiary corporation, or both. $\S 355(\mathrm{a})(1)(\mathrm{B})$. This subsection also provides that the inere sale or exchange of stock or securities of either corporation, subsequent to the distribution, shall not indicate that the transaction was used principally as a device, unless the sale or exchange was "pursuant to an arrangeinent negotiated or agreed upon prior to the distribution." $\$ 355(\mathrm{a})(1)(B)$. The regulations provide that a subsequent sale, whether or not arranged prior to the distribution, is evidence of a device. Treas. Reg. $\S 1.355-2(b)(1)(1960)$. The proposed regulations take a tougher stance toward subsequent sales of stock. First, they provide that if a subsequent sale of $20 \%$ or more of the stock of either corporation is negotiated prior to the distribution, the distribution is a device for the distribution of earnings and profits. If part or all of the securities, or less than $20 \%$ of the stock, of either corporation is subsequently sold pursuant to such a prior arrangement, this fact is considered "substantial evidence" of a device. Regardless of prior understandings, if stock or securities of either corporation are sold after the distribution is effected, the sale is an evidentiary factor to be weighed in determining whether the transaction is principally a device. Proposed Treas. Reg. \& 1.355-2(c)(2).

As noted by Professors Bittker and Eustice, the device clause and its interpretation in the regulations, as applied to pre-arranged sales of stock of one of the corporations, "serves to insure a continuity of interest on the part of the shareholders; they will be unable to cash in on their investment as part of the divisive transaction." BITTKER \& EUSTICE, supra note 135, I 13.06, at 13-30. Allowing the use of a rights offering in which the rights are freely transferable, in connection with a corporation division, is inconsistent with this purpose of the device clause and the continuity-of-shareholder-interest requirements as described by Professors Bittker and Eustice. When rights to purchase the subsidiary's stock are issued, the shareholders are given the option to sell the rights and thereby cash in on their investment in the subsidiary corporation. The statute does not otherwise state plainly that rights can be used in connection with section 355 . Arguably, 
sion and the introduction of new shareholders as owners of the subsidiary.

Finally, the Tax Court's general approach in Redding toward the applicability of section 355 to a rights offering seems to contradict the Supreme Court's directive im Gordon that the specific requirements of the statute be applied. For example, the Tax Court stated:

[W] still decide tax consequences . . on the basis of what has taken place. ...

As a general matter, a series of related steps designed and executed as part of a unitary plan to achieve a particular result is to be viewed as a whole, whether the effect of so doing is rehef from or imposition of tax, where the substance of the transaction is comprehended within a pertinent revenue statute. . . .

Inclusion of this step [the issuance of the rights] in the overall stock distribution plan by Water Co. has in no way offended the purpose of section 355. Under the facts of this case, manipulation of the instant situation for tax avoidance purposes cannot be found to have existed. ${ }^{163}$

This "purpose" or "substance" approach is inconsistent with a straightforward application of the language in section 355. The Tax Court simply believed that Water had an adequate business purpose for the distribution of the Shorewood stock through a rights offering, and that such a distribution created no tax avoidance problems. This belief may yield a "correct" result insofar as it allows businesses simultaneously to divide the corporate entity and raise capital without the interference of tax consequences to the shareholders of the parent corporation, but this result does not yield a rational interpretation of section 355 as it now stands. The language of the statute yields but one reasonable interpretation: Congress contemplated a corporate division annong the existing shareholders of the corporation. It did not mean to provide the shareholders of the parent corporation with an opportumity to sell their interests in the subsidiary corporation simultaneously with a division of the parent and subsidiary corporations. The Tax Court should be reminded of Judge Friendly's chiding remarks in his dissent in Gordon:

Congrcss has simply not seen fit to exempt all distributions where stockholders' investments reinain unchanged from a practical standpoint and no tax avoidance motive is manifest; instead it has chosen to lay down extremely specific conditions which a corporation must follow at its peril if it desires to achieve nonrecognition for its stock-

then, the use of rights should not be "read into" the statute, since their use is logically inconsistent with other express requirements of the statute.

163. 71 T.C. at 610,611 . 
holders . . . 164

In accordance with this statement, Congress has not as yet seen fit to exempt from taxation the distribution of rights to shareholders of a parent corporation to purchase the stock of a subsidiary corporation. Agaim, as a policy matter, it can be argued that the valid busmess objectives intended by this technique should be allowed without tax consequences to those shareholders who choose to exercise their rights and thereby retain their ownership interests in the subsidiary corporation, but the courts sliould leave this extension of section 355 to congressional consideration.

\section{CONCLUSION}

The Palmer dictum, that the issuance of an option is not a distribution of corporate earnings to shareholders, continues to influence the courts, as illustrated by the Baumer and Redding opinions. The intense criticism of the judicial results flowing from that dictum-its failure to recognize the economic value and property rights associated with the option itself, and its creation of substantial administrative problemscompelled the Fifth Circuit in Baumer to distimguish the facts of Palmer and to narrow the dictum without expressly overruling it and without holding that the 1954 Code had overruled it. The Service expressly stated in Revenue Ruling 70-521 ${ }^{165}$ that the Palmer dictum was overruled by the 1954 Code, but it has yet to assess a deficiency in a situation in which a court has specifically ruled on that poimt. As argued in this Article, the objectives sought by the Service and by the Fifth Circuit in Baumer are correct, although accomplished by slightly different approaches. It is arguably permissible for a court to amend the forty-year legacy of Palmer by holding that the 1954 Code treats the distribution of an option as a distribution of property within the meaning of section 301. This Article has suggested instead that Congress address the issue by amending Subchapter $C$ expressly so to provide, and by addressing the subsidiary timing questions that will inevitably arise from that change.

The contimued uncertainty surrounding the taxation of options under section 301 also affects the determination of the appropriate tax consequences of a rights offering in a section 355 transaction. The Government's position, that the distribution to parent shareholders of rights to purchase subsidiary stock is not a nonrecognition event under section 355, seems correct both according to the express statutory lan-

164. 382 F.2d at 512 .

165. $1970-2$ C.B. 72. 
guage and from the apparent intent of the statute to apply to corporate divisions in which the shareholders of the parent corporation continue their ownership interests in the subsidiary. To allow parent shareholders the choice of selling or retaining their interest in the subsidiary is incoinpatible with this present statutory intent. Nevertheless, the continued existence of the Palmer dictuin - that the issuance of an option is not a distribution of corporate property-allows the Tax Court to conclude, as it did in Baan and Redding, that the issuance of the option is procedural, and that the distribution of property for purposes of section 355 occurs when that option is exercised. If the Palmer dictum were rejected so that the issuance of the option was a taxable event under section 301, it would inean that the Government's position that section 355 does not apply to the distribution of rights is also correct, since it would be imcongruous with the rejection of the Palmer dictuin to continue to view the issuance of rights as a procedural step in a section 355 transaction. In any subsequent case the court should see the connection between this issue and the continued validity of the Palmer dicturn. The Tax Court in Redding failed to see the relevancy of this issue.

In the forty years since Palmer was decided, both the courts and the Service have had ample experience with the coinplexities raised by its dictuin. It is certainly time for Congress expressly to overrule that dictuin and to decide whether it desires to allow the use of a rights offering in connection with a section 355 transaction. Until such time as congressional attention is brought to bear on these two matters, the courts, recognizing the economic unreahty of the dictum and the administrative probleins created by its application, should reject its continued validity in the context of the issuance of taxable stock rights. They should also reject the use of rights in connection with a section 355 transaction. Judicial activisin in this area is less appealing than congressional correction of these problems, but the piecemeal approach provided by a judicial solution is better than continuing the present "state of the art" of the taxation of options issued to shareholders.

\section{APPENDIX}

Two different types of amendments to Subchapter $C$ of the Code could be made to require that the distribution to a shareholder of an option to purchase property owned by the distributing corporation be treated as a section 301 
distribution at the time of distribution rather than at the time of excercise. The first approach is the simpler. The definition of "property" in section 317 (a) could be amended specifically to include an option or right to purchase property owned by the corporation. This type of amendinent would leave for judicial developinent, or for new Treasury Regulations under section 301, solutions to problems associated with options that do not have a readily ascertảinable fair market value. In the alternative, Congress could add to Part I of Subchapter $\mathrm{C}$ a new section that specifically covers the issuance of such options. Since there is no economic difference between the issuance of options to employees as compensation and to shareholders as dividends, this new section could be modeled after section 83 of the Code. It may, however, be questionable whether it is necessary to include such a detailed provision in Subchapter C. If most options issued to shareholders do not have an ascertainable fair market value when issued, then even if the issuance of the option is treated as a section 301 distribution, the taxation of the distribution must be left open until the option is exercised. This is the same result as that obtained under Palmer. Thus, such a statute would, in effect, overrule Palmer only with respect to options with an ascertamable fair market value, and would otherwise codify the Palmer doctrine for application to options that do not have an ascertainable fair inarket value. Both results are important enought to inerit the addition of the new section. First, as discussed in the Article, if an option has an ascertainable fair market value, it is correct to treat it as a distribution when issued. Second, a codification of the Palmer doctrine as it applies to options that do not liave an ascertainable fair narket value when issued is useful to override the incorrect parts of the doctrine developed by the lower courts, sucl as the "lesser of" rule in Choate, and to provide specific answers to the types of questions raised in this Article that the courts have never definitely answered. The most significant problem raised by this proposed statute, and also raised by section 83 , is the determination of which options have an ascertainable fair market value. Different tax consequences occur depending upon the answer to that question. This factual inquiry can place the Service and the taxpayer at odds with one another-each arguing that fair market value is ascertainable whenever it is advantageous. Thus, if Congress were to consider including in Subchapter $\mathrm{C}$ a statute that overrides the Palmer doctrine with respect to options with an ascertamable fair market value, it should study the administrative problems encountered under section 83 with the taxation of the issuance of options to einployees. If those problens are substantial, it might be preferable to allow the Palmer doctrine to continue to apply to all options issued to shareholders.

The form of a statute modeled after section 83 is suggested below. It would be added as section 308 of Subchapter $C$ of the Code. It overrides the application of Palmer to options with an ascertainable fair market value and otlerwise codifies Palmer for application to all other options issued to shareholders. Following the proposed statute are comments pertaining to each subsection of the statute. If Congress were to enact such a statute, it might also amend section 305 to provide that if a right to purchase a corporation's own stock is taxable under section 305(b), then the tax consequences of the issuance of that right are also determined under section 308 . 


\section{SECTION 308. DISTRIBUTION OF OPTIONS}

(a) GENERAL RULE.-If an option to purchase property (as defined in section $317(a)$ ) is distributed by a corporation to a shareholder with respect to its stock, the excess of-

(1) the fair market value of such option (determined without regard to any restriction other than a restriction that by its terms will never lapse), over

(2) the amount (if any) paid for such option, shall be treated as a distribution of property to which section 301 applies.

(b) Nonapplication of Subsection (a).-Subsection (a) shall not apply to the distribution of an option without a readily ascertamable fair market value. In such a case, the shareholder shall be treated-

(1) in the event of a sale of the option before it is exercised, as having received on the date of the sale,

(A) to the extent of the amount realized on the sale, ordinary income equal to the amount that would have been taxed as a dividend under section 301(c)(1) if the option had been exercised on the date that it was sold; and

(B) to the extent that the amount realized on the sale exceeds the amount treated as ordinary income under (A), as gain from the sale of such option; or

(2) in the event of the exercise of the option, as having received on the date of the exercise a distribution of property to which section 301 applies in the amount of the excess of-

(A) the fair market value of the property received pursuant to the exercise of the option on the date of the exercise, over

(B) the amount (if any) paid for the property pursuant to the exercise of the option.

\section{(c) Certain Restrictions That Will Never Lapse.-}

(1) Valuation.-In the case of an option subject to a restriction that by its terms will never lapse, and that allows the shareholder to sell such property only at a price determincd under a formula, the price so determined shall be deemed to be the fair market value of the property unless established to the contrary by the Secretary, and the burden shall be on the Secretary with respect to sucli value.

(2) Cancellation.-If, in the case of an option subject to a restriction that by its terms will never lapse and to which subsection (a) applies, the restriction is cancelled, then, unless the shareholder establishes-

(A) that such cancellation was not a distribution of property to which section 301 applies, and

(B) that the corporation will treat the cancellation as not a distribution of property to which section 301 applies, as evidenced in such manner as the Secretary shall prescribe by regulations, the excess of the fair inarket value of the option (computed without regard to the restriction) at the time of cancellation over the sum of-

(C) the fair market value of such option (coinputed by taking the 
restriction into account) immediately before the cancellation, and

(D) the amount (if any) paid for the cancellation, shall be treated as a distribution of property to which section 301 applies for the taxable year in which such cancellation occurs.

(d) Holding Period.-The period for which the shareholder has held an option to which this section apphies shall include only the period beginning on the date that the option was taxed to the shareholder under subsection (a).

(e) LAPSE OF OPTION.-If the distribution of an option has been taxed to the shareholder under subsection (a) or (c) and the shareholder fails to exercise the option prior to the lapse of the option, the option shall be deerned to have been sold or exchanged on the day it expired.

(f) Modification, Extension, oR Renewal of Option.-If the terms of any option to which this section applies are inodified, extended, or renewed, such inodification, extension, or renewal shall be considered as the granting of a new option.

(g) Treatment by the Distributing Corporation.-

(1) Time of Distribution.-In the case of the distribution of an option to which this section applies or a cancellation of a restriction as described in subsection (c), the corporation that made such distribution or cancellation shall be treated as making a distribution of property to which section 301 applies for purposes of section 312 in the taxable year in which or that ends the taxable year in which such a distribution is deemed to have occurred under subsection (a) or (b)(2) or such cancellation occurred under subsection (c).

(2) Recognition of Gain or Loss.-

(A) Section 311 shall not apply to the exercise of an option to which this section apphies.

(B) Upon the exercise of an option to which subsection (a) or (b)(2) applies, the distributing corporation shall recognize a gain (if any) equal to the excess of the amount of inoney received plus the fair market value of property (other than money) received from the shareholder pursuant to the exercise of the option over the corporation's adjusted basis in the property subject to the option. Such gain shall be characterized in accordance with the character of that property in the hands of the corporation.

(C) No loss (if any) shall be recognized by the distributing corporation upon the exercise of an option to which subsection (a) or (b)(2) apphies.

(h) Definitions.-

(1) Options.-For purposes of this section, the term "option" includes a right to purchase property (as defined in section $317(a)$ ). 
(2) Shareholders.-For purposes of this section, the term "shareholder" includes a holder of convertible securities or of rights to acquire stock of the distributing corporation.

\section{Comments}

Subsection (a). This subsection provides the general rule that the excess of the fair market value of an option distributed to a shareholder over the amount (if any) paid by the shareholder for the option is treated as a distribution of property under section 301. This subsection therefore treats the issuance of the option itself rather than the exercise of the option as a distribution taxable under section 301 .

Subsection (b). This subsection incorporates the open transaction doctrine by providing that if the option when issued does not have a readily ascertainable fair market value, the shareholder is not treated as having received a distribution of property under section 301 until he exercises the option. If the shareholder sells the option, he is treated as anticipating the ordinary incoine that he would have realized if he had exercised the option on the date of sale. Sections 116 and 243 do not apply to such ordmary imcome.

Subsection (c). This subsection, which tracks section 83(d), handles certain problems associated with the issuance of options restricted by conditions that by their terms never lapse.

Subsection (d). This subsection provides that the shareholder's holding period for an option begins when the option is taxed to the shareholder under subsection (a).

Subsection (e). If the value of the option is taxed to a shareholder under section 301 as a result of the apphication of this proposed section, and if the shareholder allows the option to lapse, the option is deemed to have been sold or exchanged on the date that the option expired. If the option is a capital asset in the hands of the shareholder, he thereby realizes a short-term or longterm capital loss, depending on the period for which he has held the option.

Subsection $(f)$. This subsection is identical to section $425(\mathrm{~h})(1)$. Under this subsection, a modification, extension, or renewal of an option is treated as the grant of a new option. Consequently, the old option is deemed to have expired. If the receipt of the old option has never been taxed to the shareholder under section 308, then its expiration has no tax consequence. If the receipt of the old option has been taxed to the shareholder under section 308 , then the lapse of the old option should be taxed in accordance with subsection (e) of section 308 .

Subsection (g). This subsection provides certain tax consequences to the corporation as a result of the distribution of an option. It first provides that for purposes of the adjustinent to earnings and profits under section 312 , the time 
of the distribution is the same as the time determmed under subsections (a), (b)(2), or (c). Second, it provides that section 311 does not apply to determine whether the corporation recognizes a gam or loss as a result of the exercise of an option. Rather, a corporation never recognizes a loss as a result of the exercise of an option and does recognize a gain to the extent that the option price exceeds the corporation's adjusted basis in the property sold pursuant to the exercise of the option.

Subsection (h). This subsection provides that the word "option," as used in this proposed section, includes the distribution of "rights" to purchase corporate property. It also includes within the definition of "shareholders" subject to this section those persons who own convertible securities in the distributing corporation and who own rights to purchase the corporation's own stock.

This proposed section, like section 83 , contains no specific provisions relating to the statute of limitations. Thus, the existing statute of limitations rules apply, subject to judicial nitigation doctrimes and to the mitigation provisions of sections 1311 to 1314. 